\title{
Ecosystem function and services provided by the deep sea
}

\author{
A. R. Thurber ${ }^{1}$, A. K. Sweetman ${ }^{2}$, B. E. Narayanaswamy ${ }^{3}$, D. O. B. Jones ${ }^{4}$, J. Ingels ${ }^{5}$, and R. L. Hansman ${ }^{6}$ \\ ${ }^{1}$ College of Earth, Ocean, and Atmospheric Sciences, Oregon State University, Corvallis, OR 97331, USA \\ ${ }^{2}$ International Research Institute of Stavanger, Randaberg, Norway \\ ${ }^{3}$ Scottish Association for Marine Science, Scottish Marine Institute, Oban, Argyll, PA37 1QA, UK \\ ${ }^{4}$ National Oceanography Centre, European Way, Southampton, SO14 3ZH, UK \\ ${ }^{5}$ Plymouth Marine Laboratory, Prospect Place, The Hoe, Plymouth, PL1 3DH, UK \\ ${ }^{6}$ Department of Limnology and Oceanography, University of Vienna, Althanstrasse 14, 1090 Vienna, Austria
}

Correspondence to: A. R. Thurber (athurber@ coas.oregonstate.edu)

Received: 4 November 2013 - Published in Biogeosciences Discuss.: 25 November 2013

Revised: 19 June 2014 - Accepted: 19 June 2014 - Published: 29 July 2014

\begin{abstract}
The deep sea is often viewed as a vast, dark, remote, and inhospitable environment, yet the deep ocean and seafloor are crucial to our lives through the services that they provide. Our understanding of how the deep sea functions remains limited, but when treated synoptically, a diversity of supporting, provisioning, regulating and cultural services becomes apparent. The biological pump transports carbon from the atmosphere into deep-ocean water masses that are separated over prolonged periods, reducing the impact of anthropogenic carbon release. Microbial oxidation of methane keeps another potent greenhouse gas out of the atmosphere while trapping carbon in authigenic carbonates. Nutrient regeneration by all faunal size classes provides the elements necessary for fueling surface productivity and fisheries, and microbial processes detoxify a diversity of compounds. Each of these processes occur on a very small scale, yet considering the vast area over which they occur they become important for the global functioning of the ocean. The deep sea also provides a wealth of resources, including fish stocks, enormous bioprospecting potential, and elements and energy reserves that are currently being extracted and will be increasingly important in the near future. Society benefits from the intrigue and mystery, the strange life forms, and the great unknown that has acted as a muse for inspiration and imagination since near the beginning of civilization. While many functions occur on the scale of microns to meters and timescales up to years, the derived services that result are only useful after centuries of integrated activity. This vast dark habitat, which covers the majority of the globe, harbors processes that directly impact humans in a variety of ways;
\end{abstract}

however, the same traits that differentiate it from terrestrial or shallow marine systems also result in a greater need for integrated spatial and temporal understanding as it experiences increased use by society. In this manuscript we aim to provide a foundation for informed conservation and management of the deep sea by summarizing the important role of the deep sea in society.

\section{Introduction}

To meet the needs of humans, it is vitally important to improve the management of the Earth's ecosystems to ensure their conservation and sustainable use (Millennium Ecosystem Assessment (MA, 2005)). To improve this stewardship of the natural environment, it has become common practice to attempt to value ecosystems by assessing their functions and the services they provide to humans (Mace et al., 2009). This approach differentiates ecosystem functions or the processes operating in an ecosystem (Loreau, 2008) from ecosystem services, which are the benefits that people obtain from ecosystems (Armstrong et al., 2010, 2012). There is often confusion about the definition of functions and processes in an ecosystem services context, but they can be treated as synonyms providing appropriate definitions (Wallace, 2007). Here we refer to processes and functions as the interactions that occur between abiotic and biotic elements of ecosystems and habitats. The concept of ecosystem functions and services are related, whereby functions can be characterized outside a human context and may (but not all do) provide 
ecosystem services with direct or indirect human benefit (Van den Hove and Moreau, 2007).

The first step in ecosystem services evaluation is to identify and assess the full range of services provided by an ecosystem (TEEB, 2010). To guide these discussions, theoretical frameworks have been developed to help differentiate, give structure to, and provide the basis on which to evaluate the variety of ecosystem services (Beaumont et al., 2005; MA, 2005; TEEB, 2010; UK National Ecosystem Assessment, 2011; CICES: Haines-Young and Potschin, 2013; Liquete et al., 2013). These frameworks attempt to generate clarity by creating a uniform structure across all ecosystems and habitats (Wallace, 2007), a development that has been criticized because it does not follow the reality of the complex and diverse natural world we inhabit (Costanza, 2008). One of the main problems that the assessment of marine, and in particular deep-sea, ecosystem services is facing is that the established frameworks do not provide an appropriate structure to classify marine ecosystem services accurately (e.g., Liquete et al., 2013). Notably, the most appropriate description and classification of deep-sea ecosystem services was performed by Armstrong et al. $(2010,2012)$ and Van den Hove and Moreau (2007); the classification takes into account the specific characteristics of deep-sea ecosystems and acknowledges the complex and integrated nature of ecosystem processes as well as the distinct spatial and temporal scales at which deep-sea ecology and evolution operates. These authors used the Millennium Ecosystem Assessment (MA, 2005) as the foundation of their description (but included abiotic factors that are crucial in the context of deep-sea ecosystem services), using supporting, provisioning, regulating, and cultural services (MA, 2005; Mace et al., 2009). Supporting services are those that are necessary to produce other ecosystem services, provisioning services are products used by humans that are obtained from ecosystems, regulating services are the benefits obtained from the regulation of ecosystem processes, and cultural services are the non-material benefits people obtain from habitats and ecosystems (Armstrong et al., 2010, 2012; CICES, 2012). In an extensive review of ecosystem services publications on marine issues (Liquete et al., 2013), the MA (2005) was the most-used ecosystem services framework, illustrating its wide and established use in marine ecosystem services assessments. Although this framework has been criticized as reducing the focus on mechanisms underpinning the system (e.g., O'Neill, 2001), the ecosystem function and services assessment framework (MA, 2005) gives decision makers a mechanism to identify options that can (1) improve the achievement of human development and sustainability goals, (2) better the understanding of the trade-offs involved - across sectors and stakeholders - in decisions concerning the environment, and (3) align response options with the level of governance where they can be most effective. Moreover, the separation inherent to this framework allows for the clear identification of deep-sea functions and services needed to establish the mechanistic links that will increase our understanding of how deep-sea functions and services contribute to human welfare.

The deep sea, defined here as waters and seafloor deeper than $200 \mathrm{~m}$ (Gage and Tyler, 1991), is the largest environment on Earth - the seafloor represents $63 \%$ of the area and the water column represents $\sim 98.5 \%$ of the volume of the planet that can be permanently inhabited by animals. Its role in driving nutrient regeneration and global biogeochemical cycles is essential for sustaining primary and secondary production in the oceans (Danovaro et al., 2008b). In addition, it supports a high diversity of habitats and species (Hessler and Sanders, 1967; Grassle and Maciolek, 1992; Sogin et al., 2006; Ramirez-Llodra et al., 2010; Mora et al., 2011) as well as huge mineral resources (Herzig and Hannington, 1995; Kato et al., 2011). Deep-sea habitats receive much less attention than environments closer to home, as they are inhospitable to humans, remote and there are numerous challenges associated with studying this environment directly. As a result, this has delayed the acknowledgement of the vitally important ecosystem functions and services the deep sea provides (but see Armstrong et al., 2012). Unfortunately, this comes at a time when services from the deep sea are in increasing demand and under great pressure for its products (Mengerink et al., 2014), such as those from fishing, hydrocarbon extraction, and mining, all of which are expanding (e.g., Morato et al., 2006; Benn et al., 2010). Furthermore, the buffering capacity of the deep ocean is vital for mitigating the climatic changes caused by anthropogenic emissions. Here we review current knowledge on the functions and services provided by the deep sea, providing a foundation of knowledge for effective management, while identifying the traits that differentiate deep-sea habitats from other global biomes. Whilst it is not our intention to provide a comprehensive classification of deep-sea ecosystem services that fits with existing frameworks, we want to provide the reader with an overview of the importance of the functions and/or processes that take place in the deep sea, the complexity and integration of these processes and their scalability, and how they contribute to ecosystem services that benefit humankind.

\subsection{Major deep-sea habitats}

The pelagic deep sea below $200 \mathrm{~m}$ comprises $\sim 95 \%$ of the volume of the ocean and harbors on the order of $10^{28}$ prokaryotes (Whitman et al., 1998), a great diversity of fish, and large pelagics such as the infamous giant squid (Architeuthis spp.). In addition, this habitat provides a foraging ground for surface predators including fish, pinnipeds, and cetaceans. In general, this high-pressure, dark environment is primarily cold and well oxygenated. However, wide environmental variations do occur throughout the deep ocean, including the hypoxic to anoxic waters of oxygen minimum zones (OMZs); these relatively small areas $(\sim 0.1 \%$ 
of the ocean's volume; Codispoti et al., 2001) harbor significant biogeochemical processes including denitrification and anaerobic ammonium oxidation (anammox; Paulmier and Ruiz-Pino, 2009; Lam and Kuypers, 2011). Other chemically and thermally diverse deep-sea pelagic habitats include hydrothermal vent plumes (de Angelis et al., 1993; Dick et al., 2013) and the water column above cold seeps (Wakeham et al., 2003; Tavormina et al., 2008) that are hotspots of microbial diversity and are an area where the pelagic environment gains energy from the seafloor. While this may be the largest habitat on the globe, it also remains the least known and understood.

The deep-sea floor is generally made up of soft-sediment habitats that are treated as different environments based on their depth. The continental margins extend from a water depth of $\sim 200$ to $\sim 4000 \mathrm{~m}$, whilst the abyssal plains occur from $\sim 4000$ to $6000 \mathrm{~m}$ (Smith et al., 2008; Levin and Dayton, 2009; Ramirez-Llodra et al., 2010). Combined, these two habitats account for $\sim 85 \%$ of the total deep seafloor. Separating the ocean basins are large underwater volcanic mountain ranges, which are termed mid-ocean ridges. These chains extend up to $55000 \mathrm{~km}$ in length and cover $\sim 9.2 \%$ of the ocean floor (Ramirez-Llodra et al., 2010). In contrast to these topographic highs, deep valleys, or trenches, are formed along subduction zones, where they punctuate the bathyal and abyssal habitats and range in depth from 6000 to $11000 \mathrm{~m}$ and cover $2 \times 10^{6} \mathrm{~km}^{2}$ (Harris et al., 2014).

In addition to broad-scale deep-sea habitats, there are many smaller habitats that add to the heterogeneity and diversity of the deep sea. Some of the more pervasive, important regional habitats include seamounts, canyons and channels, fjords, hydrothermal vents, and methane seeps (RamirezLlodra et al., 2010; Treude et al., 2011; Fig. 1). Seamounts, large underwater mountains, occur either singularly or as a chain and rise up in stark contrast to the surrounding "featureless" seafloor (Rowden et al., 2005; Narayanaswamy et al., 2013). These undersea mountains comprise a mixture of soft and hard substrata and often harbor numerous fragile, vulnerable and long-lived epifauna that create areas of high biodiversity and rich fishing grounds (Clark et al., 2008, 2010; Chivers et al., 2013; Fig. 1f) that together cover $3 \%$ of the globe (Harris et al. 2014). Canyons form deep incisions on the margin, where they act as conduits for shelf-slope exchange and create essential habitats for the local fauna (Sardá et al., 2009; de Leo et al., 2013; Fig. 1a) while making up $25 \%$ of the continental margins (Harris et al., 2014). They are also regions of increased biomass and productivity (de Leo et al., 2010, 2013; Vetter et al., 2010) and are subject to disturbances such as when dense water from the shelf descends down the continental slope (Canals et al., 2006) or via mass wasting events (de Stigter et al., 2007). Chemosynthetic habitats, including vents and seeps, have a very distinct highdensity faunal community associated with them (Fig. 1e). Although they do not necessarily have a high level of diversity, they do exhibit a high level of endemism; an endemism
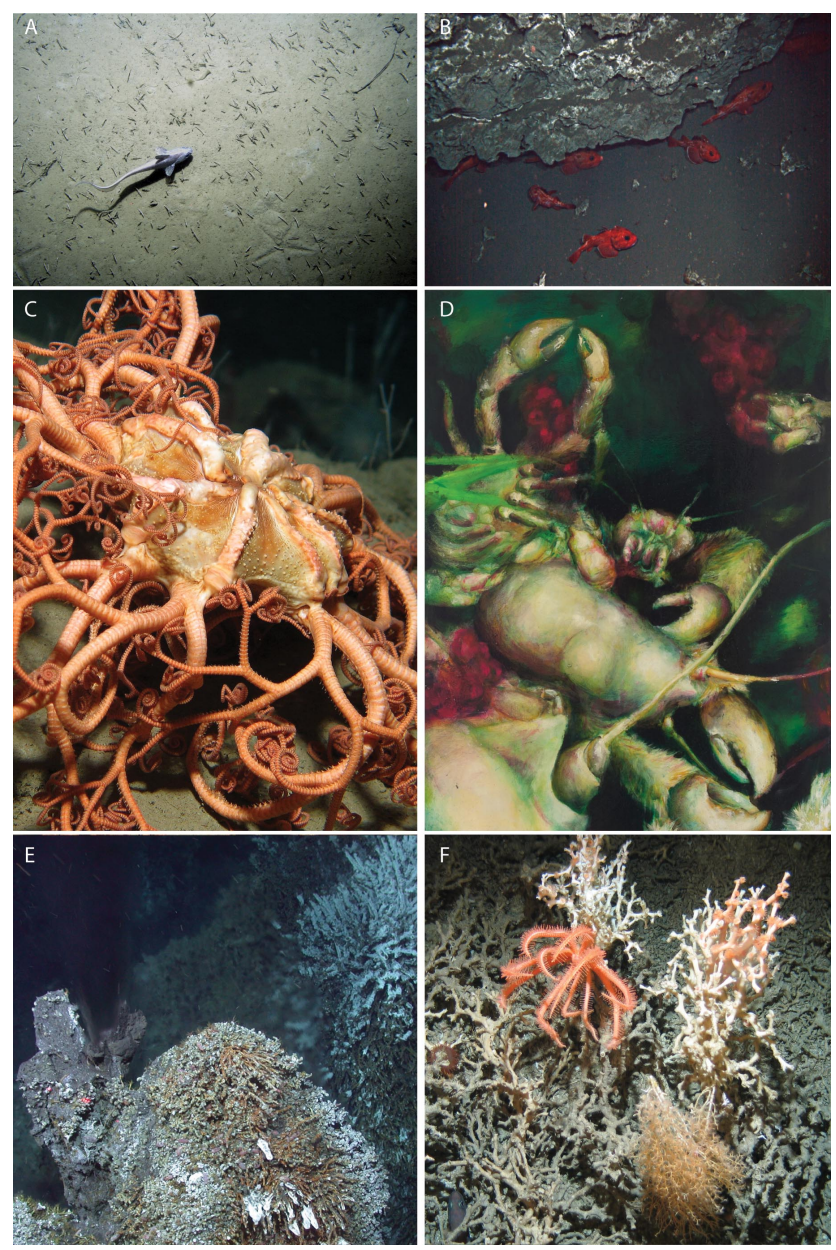

Figure 1. Examples of the species and habitats found in, and art work inspired by, the deep sea. (A) A field of the protists, Bathysiphon filiformis in Kaikoura Canyon, NZ (credit: D. Bowden (NIWA)); (B) a large authigenic carbonate at Hydrate Ridge, $\mathrm{CA}$, USA being used as a refuge by rockfish, Sebastes sp. (courtesy of L. Levin); (C) the basket star, Gorgonocephalus caputmedusae, was the first species ever sampled from the deep sea. (D) Art has been inspired by the strange fauna of the deep sea for many years. This is an example by Lily Simonson (http://oldgenres.com/), who uses deep-sea fauna as a muse for her paintings. (E) Hydrothermal vents provide areas of intense secondary production and potential resources for mining (courtesy of B. Grupe/R. Lee). (F) Ecosystem engineers, such as these deep-sea corals, provide both jewelry as well as areas of increased secondary production and demineralization (credit: Department BIS, UK).

that appears to increase with increasing depth (Levin et al., 2000). Estimates vary for how many of each of these individual habitats exist; for example, the total number of known seamounts increases with satellite and sub-sea surface exploration (Morato et al., 2013, and references therein) and other habitats are constantly being created (Biastoch et al., 2011), both of which increase the number of known deep-sea features. 
Biogenic habitats, areas of extensive three-dimensional structure created by organisms themselves, can cover tens of square kilometers of the deep seafloor (Fig. 1a and f). The structure of these habitats and the actions of their denizens can change according to the surrounding environment by shifting near-bed hydrodynamic regimes, aggregating organic matter and changing sediment characteristics (Roberts et al., 2006). Biogenic habitats often harbor high diversities of associated species as a result of increasing habitat diversity (for example providing hard and stable substratum for benthic organisms) and access to enhanced dietary resources, and provide a refuge from predators or physical disturbance. Owing to several of these characteristics, biogenic habitats provide a nursery for several deep-sea species including fish (Miller et al., 2012).

Probably the best known example of biogenic habitat in the deep sea is created by cold-water corals. Scleractinian (e.g., Lophelia pertusa, Madrepora oculata; Fig. 1f), gorgonian and antipatharian corals can form complex hard structures with their skeletons (Roberts et al., 2006). These reefs occur globally in deep waters (>300 m depth) and are colonized by a huge range of benthic and demersal organisms (Serpetti et al., 2013). In addition, many other examples of biogenic habitat occur in the deep sea. Habitats formed of large sponges and their spicules occur in many high-latitude areas (Rice et al., 1990; Gutt and Starmans, 1998; Klitgaard and Tendal, 2004; Hasemann and Soltwedel, 2011). Seabed fluid flow can often support large complex habitats comprised of clams, mussels and tube worms (Van Dover, 2000; Cordes et al., 2010a, b). Deep-sea deposit feeders, such as thalassinid shrimps and worms (including polychaetes, echiurans and sipunculans), create extensive burrow systems that irrigate and transport organic material into subsurface sediments (Levin et al., 1997; Hughes et al., 2005; Shields and Kedra, 2009), resulting in a complex three-dimensional sedimentary matrix providing particular niches for other benthic fauna such as the microscopic meiofauna and microbes (e.g., Braeckman et al., 2011; Laverock et al., 2011). Mobile epifaunal megabenthic organisms can create and modify seabed habitats in high densities, especially urchins (echinoids; Vardaro et al., 2009) and sea cucumbers (holothurians; Billett et al., 2010), and large beds of featherstars (crinoids; Bowden et al., 2011). Even large-sized singlecelled eukaryotic microorganisms, protists, can form extensive habitats and alter local biodiversity. These include xenophyophore (a multinucleate protist) grounds in many deepwater areas (Levin, 1991) and beds of the tube-forming protist Bathysiphon filiformis in submarine canyons (De Leo et al., 2010; Fig. 1a).

\subsection{Diversity and ecosystem function}

It is now well acknowledged that the deep sea has a relatively high diversity (Hessler and Sanders, 1967; Grassle and Maciolek, 1992; Rex and Etter, 2010), although this can vary dra- matically depending on the habitat being investigated (Levin et al., 2001). A general positive relationship has been established between diversity and ecosystem functioning and efficiency in a wide range of deep-sea ecosystems. However, the strength of this diversity-function relationship may differ substantially among habitats (Danovaro et al., 2012). For instance, in deep-sea sediments, species richness and diversity of functional traits are positively related to changes in species numbers affecting functional diversity and related ecological processes such as prokaryote production (Danovaro et al., 2008b). However, this relationship is stronger on continental slopes, where reduced diversity may lead to a greater loss of function in comparison to deep basins (Danovaro et al., 2012). In other slope areas there is no relationship between diversity and ecosystem function measurements such as sediment community oxygen consumption and bacterial biomass (Leduc et al., 2013). It is often assumed that the positive relationship between biodiversity and ecosystem function can reach saturation (Loreau, 2008). After this level has been reached, there is the potential for species with particular ecological traits that may enhance the overall functioning of the ecosystem (including ecosystem engineers, e.g., coldwater corals) to increase in dominance or for species to become established that may deteriorate ecosystem processes (e.g., the king crabs found on the western Antarctic Peninsula shelf that has reduced megafaunal abundance; Smith et al., 2012). In addition, it is thought that these more diverse systems induce a complementarity between species with facilitation and resource partitioning leading to overall higher function (Loreau et al., 2001). Facilitative, or positive, interactions between species may contribute positively to ecosystem function, whilst other, more negative, interactions such as selective predation and niche displacement may counteract an increase in function. Whatever the causal processes underlying deep-sea diversity and ecosystem function, the richness and variety of organisms in the deep sea are important, as they underpin the many facets of ecosystem function and the goods and services we ultimately receive (e.g., biodiversity supports the ability of the deep-sea sedimentary ecosystem to use the photic zone's primary production, its ability to use and recycle organic matter deposited on the seafloor and its ability to channel detritus to higher trophic levels; Danovaro et al., 2008b). In addition, biodiversity contributes to ecosystem resilience, a supporting service (cf. Armstrong et al., 2013), with increased morphological, genetic and functional diversity leading to greater stability in terms of being able to respond rapidly to changes in the environment. A variety of recent papers have discussed this topic in detail (e.g., Loreau, 2008; Levin and Dayton, 2009; Leduc et al., 2013). In addition to the aforementioned services, we should also note that biological regulation is a regulating service resulting from biodiversity itself (i.e., interactions between species and genotypes, including biological pest control, trophic transfer and interactions). Biodiversity also includes supporting services that need to be considered 
as necessary for the production of all other - more direct ecosystem services, including its influence on primary production and nutrient cycling (Armstrong et al., 2012).

\section{Supporting and regulating functions and services}

\subsection{Water circulation and $\mathrm{CO}_{2}$ exchange}

Many of the functions and services of the deep sea result from a combination of its vast size and the long duration of time that it is separated from the Earth's atmosphere. The water masses that bathe the deep-sea environment are formed largely in the North Atlantic and the Southern Ocean, with additional input from the Sea of Okhotsk and the Mediterranean and Red seas. As soon as these cold (mean temperature $4{ }^{\circ} \mathrm{C}$ ) dense water masses sink below the photic zone, they are cut off from the atmosphere for approximately 1000 years, supplying all the world's deep ocean areas in the "global conveyor belt" also known as the "thermohaline circulation" that eventually resurfaces in areas of upwelling and the North Pacific. This creates more than one billion square kilometers of water separated from direct contact with the atmosphere, allowing an incredible buffering capacity for nutrient and carbon cycles. Water circulation is generally recognized as a supporting service, but it is the buffering capacity that also renders it a regulating service to the benefit of other ecosystem services such as nutrient cycling, climate and weather regulation in part and, importantly, $\mathrm{CO}_{2}$ exchange.

Since the industrial revolution $\sim 300$ Gton of the greenhouse gas $\mathrm{CO}_{2}$ has been released by anthropogenic activities into the atmosphere (Canadell et al., 2007; Fig. 2). The impact of this $\mathrm{CO}_{2}$ on the temperature of the globe is largely mediated by dissolution of this gas in the surface ocean and its transport through the thermohaline circulation into the deep sea. The deep sea currently stores approximately 37000 Gton of carbon and has already absorbed a quarter of the carbon released from human activities (Canadell et al., 2007; Sabine and Feely, 2007); this $\mathrm{CO}_{2}$ absorbance is a very important regulating service influencing climate and many other deep-sea functions and services.

\subsection{Nutrient cycling and the biological pump}

As particles sink through the water column, they are stripped of their easy-to-digest (labile) compounds, releasing nutrients and energy into the deep sea. This process, termed the biological pump, both sequesters atmospheric carbon and releases nutrients that eventually fuel production (Fig. 2). The vast majority of the deep sea relies on this primary production that occurs in surface waters (i.e., photosynthesis by phytoplankton). As these particles sink through the deep pelagic, they are degraded by microbes and higher trophic levels, such as zooplankton and especially large gelatinous fauna (Robison, 2004). This biological activity dictates the duration that the exported carbon is separated from the atmosphere. If biomass is respired in the water column or on the seafloor, this carbon will be kept out of the atmosphere until the water rises to the surface again and releases the carbon back (1000-year timescales). However, if this carbon is buried in sediments, the $\mathrm{CO}_{2}$ is removed from the atmosphere for geologic timescales (thousands to millions of years). Around $55 \%$ of the carbon that sinks below $1000 \mathrm{~m}$ is respired in the water column prior to its deposition on the seafloor (Jahnke, 1996), leaving only $\sim 1 \%$ of the carbon fixed at the surface to be deposited on the seafloor (Lutz et al., 2007); the majority of the carbon fixed at the surface is not exported into the deep ocean. The quantity of carbon from the surface water exponentially declines with increasing water depth (Martin et al., 1987), although the rate of decline is location specific with a more rapid decline in oligotrophic compared to eutrophic waters (Buesseler et al., 2007) and asymptotic for much of the deep sea. While most of the carbon that is deposited is difficult to digest (refractory) (Kiriakoulakis et al., 2001), areas of high deposition, including oxygen minimum zones and areas of river discharge (Berner, 1989, and see the discussion in Cowie et al., 1999), can result in labile carbon being buried within the seafloor because it is deposited faster than it can be degraded at the sediment surface. This flux of particles out of the surface waters provides a second way in which carbon is naturally captured from the atmosphere and transferred to the deep sea, further mitigating the climate impacts of $\mathrm{CO}_{2}$ emission, but over different timescales. Considering the different processes and functions associated with nutrient cycling and the biological pump, it becomes clear that these act both as supporting services (e.g., crucial to biomass production in provisioning services) and regulating services (natural carbon sequestration - reducing anthropogenic carbon in the atmosphere).

Although we focus on carbon here, the deep-sea environment plays a key role in the cycling of other nutrients such as nitrogen, silica, phosphorus, hydrogen and sulfur (Fig. 2). Specifically with regards to nitrogen cycling, microbially mediated processes including nitrification, nitrogen fixation, denitrification, and anaerobic ammonium oxidation occur in both the pelagic and benthic deep ocean, providing sources, sinks, and transformation of nitrogen among nitrogen pools (Gruber and Sarmiento, 1997; Wuchter et al., 2006; Francis et al., 2007; Ward et al., 2009; Ulloa et al., 2012; Fig. 2). Nitrogen is selectively removed from dissolved organic material throughout biological processing in the water column and sediments (Bronk, 2002; Hunter et al., 2012), and nitrogen cycling in the benthos releases nutrients such as nitrate, nitrite, and ammonium back into the water column (Laverock et al., 2011). Nutrients regenerated at the seafloor are ultimately recycled and returned back to the surface through thermohaline circulation (often in areas of upwelling) for the process to start again (Fig. 2).

Methane provides another key greenhouse gas whose potency is mitigated through deep-sea biological activity; a 


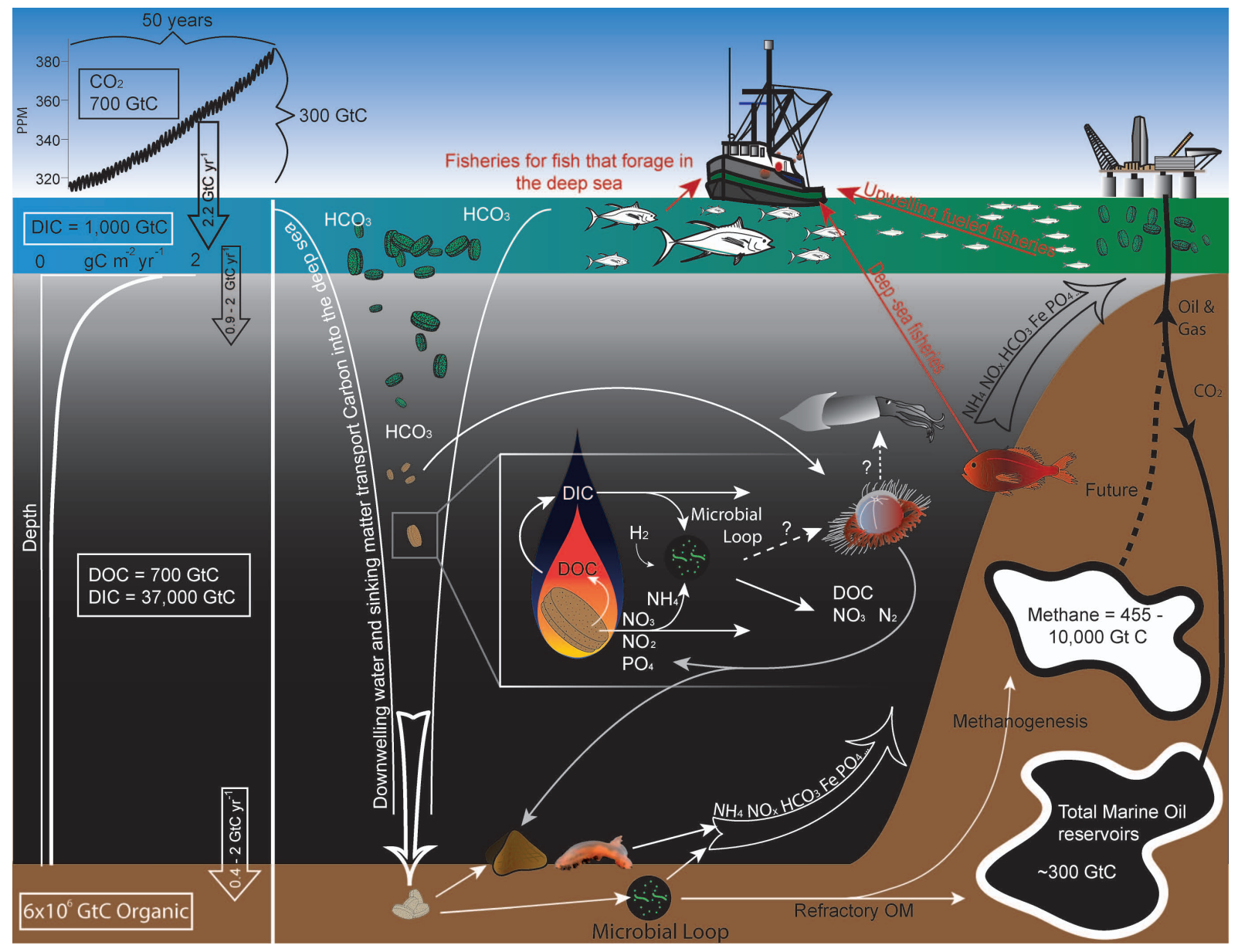

Figure 2. Schematic of carbon flow and a subset of the resources and functions of the deep sea. Data include the Keeling and Martin curves (Martin, 1987) and values from Longhurst (1991), Sabine and Feely (2007), Canadell et al. (2007), and the US EPA. Arrows represent the flow of matter or carbon and the upwelling of nutrients. Dotted lines are potential or unquantified flows. $\mathrm{NO}_{\mathrm{x}}=\mathrm{NO}_{2}$ and $\mathrm{NO}_{3}$. Not to scale.

molecule of methane is 25 times more efficient at warming our atmosphere than a molecule of $\mathrm{CO}_{2}$ (see IPCC 2007). Vast reservoirs of methane exist in the deep sea (45510000 GtC methane; Kvenvolden, 1993; Klauda and Sandler, 2005; Reeburg, 2007; Wallmann et al. 2012) and while most of this potential fuel source is kept trapped either as or by hydrates, the latter forming by the temperature and pressure pervasive there, one of the key services provided by deep-sea communities is the rapid consumption of the small proportion that is released (Reeburg, 2007; Knittel and Boetius, 2009). As a result, while methane itself provides $17 \%$ of greenhouse gas forcing, oceanic sources currently only contribute approximately $2-4 \%$ of the methane emitted into the atmosphere (Judd et al., 2002; IPCC 2007; Reeburg, 2007). The majority of methane that is released from marine reservoirs is consumed within the sediment, leaving pelagic communities to oxidize methane only in areas where there is sufficient methane release to surpass this benthic filter (sensu Sommer et al., 2006). Often this is caused by geological activity such as explosive mud volcanoes (Niemann et al., 2006; Reeburg, 2007), hydrothermal vents and cold seeps (e.g., Sommer et al., 2010), or inadvertent hydrocarbon releases (Valentine et al., 2010; Rivers et al., 2013). As an added benefit, the anaerobic oxidation of methane leads to the precipitation of authigenic carbonates, creating an additional trap of carbon (Aloisi et al., 2002), sequestering it for an indefinite time period. While this service of consuming methane may largely be keeping methane sources in check, at times throughout Earth's history perturbations have released these methane reservoirs, causing massive extinction events, including a loss of $>70 \%$ of marine invertebrate species 183 mya (Kemp et al., 2005). Thus the marine oxidation of methane is a function inherent to deep-sea benthic primary (chemosynthetic) production, which is a supporting function, but at the same time it provides a regulating service (i.e., reducing geological and biological methane release, promoting carbonate precipitation and habitat formation) with indirect benefits to human populations. In addition to benthic primary production, we also need to consider chemosynthetic primary production in the pelagic realm, where it constitutes 
a supporting and regulating service as well, as discussed below.

\subsection{In situ primary and secondary production}

One of the greatest paradigm shifts in the past decade is the role of chemosynthetic production in non-"extreme" deepsea environments (Middelburg, 2011). Organisms attached to sinking particles produce hydrolytic enzymes that transfer organic material from the sinking particles into the water column at a rate faster than at which it is consumed (Fig. 2). This imbalance in enzyme efficiency and consumption results in a "plume" of fresh dissolved organic carbon (DOC) that trails these particles as they sink, providing substrates for planktonic microbes in the deep ocean (Smith et al., 1992; Vetter et al., 1998). Although the DOC pool in the deep ocean is approximately equal to that of $\mathrm{CO}_{2}$ in the atmosphere at around $700 \mathrm{GtC}$, it is largely refractory and inaccessible, even to microbes (Hansell et al., 2012). However, the significantly larger dissolved inorganic carbon (DIC) pool $(\sim 38100 \mathrm{GtC})$ is utilized by microbes in the deep sea through chemoautotrophic primary production (Ingalls et al., 2006; Hansman et al., 2009; Herndl and Reinthaler, 2013). This dark $\mathrm{CO}_{2}$ fixation is on the order of heterotrophic production (Alonso-Sáez et al., 2010; Reinthaler et al., 2010; Herndl and Reinthaler, 2013), and can be performed by both bacteria and archaea (Herndl et al., 2005). Chemoautotrophs require reduced inorganic compounds as energy sources to fuel DIC fixation, and evidence is mounting that these may include ammonia, urea, sulfide, and hydrogen (Wuchter et al., 2006; Swan et al., 2011; Alonso-Sáez et al., 2012; Anantharaman et al., 2013). Many of these compounds are often provided by the degradation of sinking organic matter.

Ultimately, secondary production, the formation of biomass fueled by organic carbon degradation and assimilation, is arguably the primary function resulting in the provision of biomass for human consumption, most notably finfish, shellfish, and cetaceans (treated below in the provisioning section). Additionally, this production is the result of respiration - where $\mathrm{CO}_{2}$ is released and oxygen consumed and thus is involved in the regulation of gas cycling and carbon sequestration in the deep sea. Secondary production is driven by the quality and quantity of the food resources available (Ruhl et al., 2008; Smith et al., 2008). Depth is often cited as the driving factor of secondary production as a result of reduced particulate organic carbon (POC) flux at greater depths; however, interannual variability and total surface production also impact the distribution of biomass (Ruhl et al., 2008; Wei et al., 2010). Despite this clear benthic-pelagic link, deep ocean communities' carbon demand can exceed the vertical supply, with this imbalance being potentially met by lateral advection or by food resources not accounted for in current assessments (Burd et al., 2010). A similar situation is observed in submarine canyons and trenches, which act as depocenters by topographically channeling organic matter, allowing biomass to exceed that of other deep-sea habitats by orders of magnitude (de Leo et al., 2010).

While secondary production is difficult to measure directly, it can be estimated as a function of benthic biomass, trophic transfer efficiency, and metabolic rate. Compared to the rest of the marine environment, the deep-sea floor is estimated to contain $78.9 \%$ of the total benthic biomass; $50 \%$ of total marine benthic biomass is found below $3000 \mathrm{~m}$ (Wei et al., 2010). Deep-sea floor biomass is also high at high latitudes, with over a quarter of global biomass contained within the $13.4 \%$ of the seafloor found at $>60^{\circ} \mathrm{N}$ or S (Wei et al., 2010). Whilst the nuances of how depth and organic matter input influence secondary production remain debated, the total biomass of all benthic size classes generally declines with increasing water depth from the continental margins to the abyssal plains. The exceptions to this are bacteria, which dominate the biomass of the abyssal plain and below (Wei et al., 2010). Thus the activities of microbes, including their respiration and biochemical processes (e.g., nitrification/denitrification, amino acid oxidation), are a key component as to the type and abundance of nutrients released back into the pelagic realm. These microbes also experience topdown forcing from viral populations (Suttle, 2005; Danovaro et al., 2008a) and grazing by many size classes of animals (e.g., Howell et al., 2003, Ingels et al., 2010). In addition, the faunal-bacterial interactions within the benthic food web regulate uptake of $\mathrm{C}$ and $\mathrm{N}$ (Hunter et al., 2012). The overall production by animals is further influenced by predatory and competitive interactions, facilitation and complementarity among species, and environmental drivers such as temperature and oxygen availability. For example, low oxygen tends to reduce macrofaunal abundance and biomass, while leading to increased densities of meiofauna and bacteria (Levin, 2003). The suite of interactions forms regulating services that affect the magnitude and complexity of secondary biomass production in the deep sea (and ultimately translates into the provisionary service of fish, shellfish and other marine biological products used by humans).

A variety of habitats are created by large deposits of organic matter, including fish, whale, jellyfish, wood, and kelp "falls", creating areas of enhanced secondary and primary production on the scale of meters to tens of meters. Among the best studied of these are whale falls, where large cetacean biomass can support communities that are divergent from background communities for up to a century (Smith and Baco, 2003). However, this time period is dependent on the size of the cetacean and can be an input of energy for less than a decade. In addition, over these time periods a diversity of successional stages occurs from scavenger, to specialist fauna and finally with the bones acting as hard substrate for filter feeders. Wood and leaf deposits create an additional type of similar habitat on shelf, fjord, slope, and abyssal habitats near wooded continental margins (Wolff, 1979; Pailleret et al., 2007). These terrigenous deposits create both an additional type of carbon sequestration, while 
providing high levels of primary and secondary production to the deep-sea floor (Turner, 1977; Bernardino et al., 2010) and its associated supporting, regulating, and provisioning services. Somewhat surprisingly, many falls also result in in situ production. Degrading wood material can stimulate chemosynthetic production with trophic transfer up to fishes and lobsters (McLeod and Wing, 2007, 2009), and whale falls have worms whose heterotrophic symbionts harness the energy stored in the whales to build their biomass (Rouse et al., 2004), while free-living bacteria perform a diverse suite of chemical magic to produce energy for their cell growth from the whale (Treude et al., 2009).

Methane seep and hydrothermal vent communities provide an outlier of intense secondary production in the deep sea, both due to high levels of chemoautotrophic primary production as well as the abundance of hard substrate in these habitats. Biomasses of methane-consuming bacteria and archaea ( $3 \mathrm{~mol} \mathrm{C} \mathrm{m}^{-2}$; Boetius and Suess 2004) are directly consumed by a diversity of metazoans (Levin and Michener, 2002; Van Gaever et al., 2009; Levin et al., 2010; Thurber et al., 2012, 2013), and the flux of energy out of the benthos, largely in dissolved form (seep fluids can contain $\sim 22 \mathrm{mM}$ of dissolved organic carbon; Valentine et al., 2005), may be an important source of support for deep-sea populations. This results in a vent and seep biomass that far exceeds that of the background community; vents can be found with $>70 \mathrm{~kg}$ animal m$^{-2}$ (Gebruk et al., 2000) and seeps can exceed $30-51 \mathrm{~kg}$ animal m${ }^{-2}$ (Olu et al., 1996). Even just considering the microbial community in this context, these habitats are an important sink for oxygen (Boetius and Wenzhofer, 2013) and thus both primary and secondary production. Furthermore, the hard substrate habitat created by the microbial processes at seeps provides a habitat for corals and other ecosystem engineers that create additional hotspots of secondary production (Cordes et al., 2008; Lessard-Pilon et al., 2010) and fish (Sellanes et al., 2012; Fig. 1).

\subsection{Waste absorption and detoxification}

The deep sea provides an area where waste products are stored as well as detoxified through biotic and abiotic processes (note, however, that the deep-sea provision of space for the dumping or sequestration of waste products is considered a provisioning service; sensu Armstrong et al., 2010). Contaminant absorption onto sinking particles (reviewed in Dachs et al., 2002), dense shelf water cascades (Canals et al., 2006), and deliberate human activity (Thiel, 2003) transport pollutants from surface waters and continental shelf sediments to the deep ocean basin. These pollutants include persistent organic pollutants, macro- and micro-plastics, sewage, and oil, and can sometimes be removed through bioremediation, that can be facilitated by bioturbation. Bioturbation is considered a regulating service in the sense that - through biogenic mixing of sediments by burrowing organisms - it regulates the decomposition and/or sequestra- tion of organic wastes (Armstrong et al., 2012). Of special note to bioremediation are the organic pollutants; these accumulate in the tissue of higher predators that are harvested and thus remain a threat to humans. While pollutants transported to the deep sea could be viewed as a benefit, since it removes them from being in contact with food stocks that are harvested from the surface ocean, deep-sea fish live much longer, allowing for a greater time to concentrate these compounds, meaning that when deep-sea fish are harvested they can provide a concentrated source of pollutants to human consumers through bioaccumulation. Therefore the deposition and assimilation of these compounds in the deep sea is a temporary regulatory service if viewed as a service at all (Froescheis et al., 2000; Looser et al., 2000). A variety of biotic processes can detoxify "waste" or potential pollutants contributing to the regulating service of biological waste remediation in the deep sea. A recent example of this occurred during the 2010 Macondo oil spill (also known as the Deepwater Horizon Spill) where members of the deepsea microbial community in the Gulf of Mexico were capable of degrading hydrocarbons and gases released from the well (Valentine et al., 2010; Lu et al., 2012; Crespo-Medina et al., 2014), and recently more bacteria with the potential to oxidize hydrocarbons have been recognized (Kube et al., 2013; Naether et al., 2013).

While biological bioremediation and detoxification of compounds in the deep sea are considered regulating services (partially driven by biodiversity; see Sect. 1.2), the space that the deep sea provides to dispose of waste or sequester $\mathrm{CO}_{2}$ artificially (inherently an abiotic element) is considered a provisioning service (Armstrong et al., 2010; see Sect. 3.4).

\section{Provisioning services}

\subsection{Fisheries/nutrition}

One of the most tangible ecosystem services from the deep sea are fish stocks, which are increasingly finding their way into human diets. Overexploitation of shallow water and shelf-depth fish stocks has led to an increase in the harvesting of deeper fish stocks over the past 40 years (Morato et al., 2006, 2013). These deep-sea fisheries are one mechanism by which the energy contained in fish species from below $200 \mathrm{~m}$, and in certain cases below $1000 \mathrm{~m}$ (Bailey et al., 2009), is transferred back to the surface water and ultimately into the human food cycle. Currently at least 27 species of fish are harvested in the deep sea (Norse et al., 2012), and the mean depth of fishing is increasing at a rate of $62.5 \mathrm{~m}$ per decade (Watson and Morato, 2013). However, in many cases, these fisheries are not deemed sustainable owing to the incredibly slow growth of the species of interest (certain fish live > 100 years; Cailliet et al., 2001), the large bycatch of non-target species produced by certain fishing gears (Norse et al., 2012), and populations showing major declines 
(Bailey et al., 2009). While some fisheries are more susceptible to overharvesting than others and in some cases protective area management is implemented, even exploitation under precautionary management practices may nevertheless lead to a population decline, such as the case of the orange roughy off New Zealand, which has remained harvestable but is still in decline (Norse et al., 2012). One of the few exceptions is an artisanal fishery for black scabbardfish, which has not experienced the same decline as most other deepwater fish stocks (Norse et al., 2012). While the stocks themselves are the target, the use of trawls to capture these fish can greatly impact the services provided by the deep sea owing to damage of three-dimensional seafloor structures (Roberts, 2002; Puig et al., 2012) and the resulting impacts on biodiversity, carbon turnover, and abundance and biomass of fauna (Pusceddu et al., 2014). In addition, illegal, unregulated, and unreported fishing practices undermine sustainable fisheries management at a substantial social and economic cost (Flothmann et al., 2010).

However, one of the main links between global fisheries and the deep sea results from nutrient regeneration. The most productive fisheries in the world occur in areas of strong upwelling, where deep-sea nutrients are brought back to the surface where they fuel photosynthetic production and harvested food stocks (Fig. 2). Fisheries in these areas are some of the most productive on the planet, including the sardine and anchovy fisheries off South America, which have produced over 10 million and 5 million tons of fish, respectively, during certain years (GLOBEC NMFS 1996). In addition, many cetacean, pinniped, and fish species, including sperm whales (Physeter macrocephalus) and elephant seals (Mirounga spp.), forage in the deep sea even though they are (or historically have been) caught in surface waters.

\subsection{Oil and gas/energy}

Once oil and gas reserves on land had been proven profitable, industrial exploitation of this resource quickly moved into shallow marine areas and, in the 1960s, into offshore areas. As easily accessible resources declined, technology for offshore drilling improved, and large reserves of hydrocarbons were found, the oil and gas industry moved into deeper and deeper waters. In the Gulf of Mexico, major reserves are being accessed in waters as deep as $3000 \mathrm{~m}$. Currently drilling for oil and gas is routine in the deep sea (UK $>9000$ wells $>30 \mathrm{~m}$ depth and $328>200 \mathrm{~m}$ depth - data from the UK Department of Energy and Climate Change; Norway $1390>30 \mathrm{~m}$ and $546>200 \mathrm{~m}$ depth - data from the Norwegian Petroleum Directorate; Gulf of Mexico 3800 offshore wells - data from the National Ocean and Atmospheric Association), with major deep-water production in areas such as the Arctic, northern North Atlantic (UK and Norwegian waters), east and west Africa, Gulf of Mexico, South America, India, Indonesia, and Australia. Oil and gas revenues from offshore areas are enormous: the industry is a major em- ployer, and technological developments have many ramifications for other deep-water industries. Clearly, although this provisioning service is important, exploitation of these resources needs to proceed with caution to avoid major broadscale disturbance to the deep-sea environment, as shown dramatically by the destruction of Deepwater Horizon and the subsequent oil spill from the Macondo well affecting a large area of the Gulf of Mexico (White et al., 2012; Montagna et al., 2013).

While oil represents a utilized service, vast deposits of methane on the seafloor may be a fuel that can bridge the gap of dwindling oil supplies prior to more sustainable solutions being implemented. As a result of anaerobic respiration in the deep-sea floor by archaea, the reservoirs of methane discussed above are produced and trapped in the deep subsurface or, under certain circumstances, form methane hydrates on or below the seafloor. These reserves are extremely extensive in some areas, including the Arctic, and are globally estimated to hold twice the combustible carbon known from all other fossil fuels (Klauda and Sandler, 2005; Wallmann et al., 2012). Commercial exploitation of methane hydrates is an advancing technology, adopting similar methods to traditional oil and gas drilling activities, and several industrial concerns are considering commercial exploitation of this resource on a large scale. While the exploitation of methane reservoirs is being developed further, the potential of hydrogen generation, subsequent mixing of the produced hydrogen with natural gas, its transport via the existing pipeline network and the introduction of it into existing subsurface storage facilities as an energy reserve to be called upon in the future are also being considered (Schmitz, 2011; Pichler, 2013).

In addition to oil and gas, there are other ways in which energy can be extracted from the deep sea. One example is the collection of power from the hydrothermal vent fields using thermoelectric generators, either by tapping a temperature gradient directly from the plumes of a hydrothermal vent, or using high-pressure thermosyphons installed in a well on the hydrothermal mounds (Parada et al., 2012). Since the 1980s, ocean thermal energy conversion (OTEC) technology has provided the opportunity to harness the temperature differences between cool surface water and colder deepsea water to create electricity, and it is estimated that OTEC is theoretically capable of providing 4000 times the global energy need (Vega, 2002). The interest in the implementation of such technology on industrial scales is rising quickly with increasing energy demand globally (Yeh et al., 2005) and several (test) plants are planned or proposed worldwide (Knight, 2014), although there are still doubts as to the economic and logistic feasibility of the technology. However, on Kume Island in Okinawa, Japan, OTEC has been tested at a $50 \mathrm{~kW}$ plant since April 2013, whereby deep water $(600 \mathrm{~m})$ is pumped up to be used in convection turbines, and in Ansan, South Korea, a $20 \mathrm{~kW}$ plant is operated only in summer when the temperature difference between surface and deep 
water exceeds the $20^{\circ} \mathrm{C}$ minimum (Knight, 2014). Aside from energy, there are multiple uses for the pathogen-free and nutrient-rich cold seawater pumped up from the deep sea, such as mariculture, refrigeration, air conditioning, and the production of potable water (Dylan, 1995; Yeh et al., 2005). Despite the perception of OTEC technology as being sustainable exploitation of renewable energy, the construction of the needed large-scale deep-water infrastructure and potential alteration of oceanic thermohaline circulation because of necessary massive OTEC seawater flow rates (Nihous, 2007) means that it is a potential threat to other functions and services the deep ocean provides.

\subsection{Mining/non-nutritional materials}

A variety of processes in the deep sea leads to large areas of concentrated metals reserves on the abyssal floor, at hydrothermal vents, and in certain areas covered by rich crusts of minerals (e.g., Hein et al, 2013). Many of these metals are integral to current electronics, and since terrestrial supplies are dwindling and/or becoming harder to extract, deep-sea mineral resources are likely to be extensively mined within the next few decades. Precipitation of manganese, phosphate, and other metals around seed particles under deep-sea conditions over timescales of millions of years has produced extensive deposits of fist-sized polymetallic nodules (reaching densities of hundreds per $\left.\mathrm{m}^{2}\right)$ and crusts (thin $(<20 \mathrm{~cm})$ surficial deposits). Although these deposits occur across a lot of the world's deep water areas (Table 1), the ore quality and nodule density varies and the most likely commercial deposits are found in the Clarion-Clipperton Fracture Zone (CCFZ) in the Pacific Ocean (Glover and Smith, 2003). Seabed fluid flow and precipitation of geological minerals at the seafloor (for example at hydrothermal vents) has led to the creation of massive seafloor sulfides (SMS deposits or volcanogenic massive sulfides/VMS as it is often called within the mining literature), which contain high-grade metal ores in significant and commercially attractive quantities. The deep sea also contains areas of sediment rich in metals (Atlantis II Deep, Red Sea; Thiel, 2003), significant phosphorus deposits (Cullen, 1980; Thiel, 2003) and sediments elevated in rare Earth elements (Kato et al., 2011), which may all also be profitable to exploit. Commercial-scale mining of deep-sea mineral deposits has been considered and trialed since the 1970s. There are current exploration claims and active investigation throughout the CCFZ for manganese nodules, on the Mid-Atlantic Ridge (for SMS deposits) and production activities beginning imminently in Papua New Guinea (SMS; Nautilus Minerals). Mining is not limited to utilitarian resources; cold water corals supply both a provisioning as well as cultural service as they are harvested for jewelry (Foley and Armstrong, 2010).

\subsection{Waste disposal}

The vast depth of the deep sea makes it an area that has been used as a dumping ground for many types of waste, including radioactive substances, munitions, animal carcasses (Morton, 2003), sewage sludge, plastics, mine waste (reviewed in Thiel, 2003, and Ramirez-Llodra et al., 2011, 2013, but see Pham et al., 2014, for the most recent report on human waste in the deep sea), and munitions disposal (Thiel, 2003; HUMMA final report, 2010), in addition to being a sink or deposition area for pollutants and organic wastes. If these compounds accumulate on the seafloor, or are buried within the sediment, the habitats provide a more long-term benefit to society as a provisioning service. The slow turnover time of the deep sea (1000 years) and the low oxygen concentration (relative to air) mean that many substances disposed of in the deep sea will be sequestered in relatively stable states for long periods of time, during which some may be broken down into non- or less harmful substances (through decomposition, rusting and the aforementioned detoxification, which are regulating services; see Sect. 2.4). However, this detoxification is substance specific; some chemical weapons (of which there are some 150000 tons that were disposed of in marine habitats) will degrade and others retain their potency (Thiel, 2003). Of note, while the deep sea has been an area where radioactive waste has been disposed of (Thiel, 2003), no biotic or abiotic processes degrade or ameliorate the problems associated with this type of waste. In addition, certain munition deposits are known to cover several $\mathrm{km}^{2}$ per deposit, and have occurred in many locations around the world (see the review by Thiel, 2003).

The deep sea has also been considered a potential dumping ground for gas, because at the high pressures and low temperatures found there, certain gases, including $\mathrm{CO}_{2}$, form a fluid, easing its sequestration. However, depositing $\mathrm{CO}_{2}$ in this manner leads to the acidification of surrounding waters, with detrimental impacts on marine life (Thistle et al., 2006, 2007; Bernhard et al., 2009). These impacts may limit the expansion of $\mathrm{CO}_{2}$ deposition in the deep sea from an experimental to a realized service. A more plausible solution is to use carbon capture and storage whereby $\mathrm{CO}_{2}$ is captured and then stored under the seafloor in depleted oil, gas, or gas hydrate reservoirs or deep saline aquifers. Recently, however, concerns about potential leakage of $\mathrm{CO}_{2}$ and escape of formation water for the benthic environment have been investigated in numerous scientific projects (Wallmann and Bialas, 2009). It is also important to note that as we are seeing increasing exploitation of deep-sea resources, the areas that may currently seem opportune areas for depositing waste may be future areas of bioprospecting or fishing, activities that could be hampered by waste disposal efforts. 
Table 1. The distribution of regulating and provisioning services among the habitats present in the deep sea. Blank $=$ unknown or not present. $\mathrm{P}=$ present. $\mathrm{W}=$ widespread or abundant.

\begin{tabular}{|c|c|c|c|c|c|c|c|c|c|}
\hline & $\begin{array}{c}\text { Abyssal } \\
\text { plains }\end{array}$ & $\begin{array}{c}\text { Biogenic } \\
\text { habitats }\end{array}$ & $\begin{array}{l}\text { Can- } \\
\text { yons }\end{array}$ & $\begin{array}{c}\text { Deep } \\
\text { pelagic }\end{array}$ & Margins & $\begin{array}{l}\text { Mid-ocean } \\
\text { ridges }\end{array}$ & $\begin{array}{l}\text { Sea- } \\
\text { mounts }\end{array}$ & $\begin{array}{l}\text { Tren- } \\
\text { ches }\end{array}$ & $\begin{array}{c}\text { Vents and } \\
\text { seeps }\end{array}$ \\
\hline Alternative energy sources & & & $\mathrm{P}$ & $\mathrm{P}$ & $\mathrm{P}$ & $\mathrm{P}$ & $\mathrm{P}$ & & $\mathrm{P}$ \\
\hline Bioprospecting & $\mathrm{P}$ & $\mathrm{P}$ & $\mathrm{P}$ & $\mathrm{P}$ & $\mathrm{P}$ & $\mathrm{P}$ & $\mathrm{P}$ & $\mathrm{P}$ & $\mathrm{W}$ \\
\hline Carbon capture and disposal & $\mathrm{P}$ & & & & $\mathrm{W}$ & & & $\mathrm{P}$ & \\
\hline Communication cables & $\mathrm{P}$ & & $\mathrm{P}$ & & $\mathrm{W}$ & $\mathrm{P}$ & & $\mathrm{P}$ & \\
\hline Fisheries & & $\mathrm{W}$ & $\mathrm{W}$ & $\mathrm{P}$ & $\mathrm{W}$ & $\mathrm{W}$ & $\mathrm{W}$ & & \\
\hline Metal-rich sediments & $\mathrm{P}$ & & & & & & & & \\
\hline Methane harvesting & & & & & $\mathrm{W}$ & & & $\mathrm{P}$ & $\mathrm{P}$ \\
\hline Military & & & $\mathrm{P}$ & & $\mathrm{W}$ & $\mathrm{P}$ & $\mathrm{P}$ & & \\
\hline Oil and gas extraction & & & & & $\mathrm{W}$ & & & & \\
\hline Phosphate mining & & & & & $\mathrm{P}$ & & & & \\
\hline Polymetallic crusts & & & & & & $\mathrm{W}$ & $\mathrm{W}$ & & $\mathrm{P}$ \\
\hline Polymetallic nodules & $\mathrm{W}$ & & & & & & & & \\
\hline Rare Earth elements & $\mathrm{P}$ & & & & & & & & \\
\hline Seafloor massive sulfides & & & & & & $\mathrm{P}$ & $\mathrm{P}$ & & $\mathrm{W}$ \\
\hline Waste disposal & $\mathrm{W}$ & & $\mathrm{W}$ & $\mathrm{P}$ & $\mathrm{W}$ & & & $\mathrm{P}$ & \\
\hline
\end{tabular}

\subsection{Bioprospecting}

Resources in the deep sea are increasingly being exploited by bioprospecting, or the search for natural products within biological resources. The deep ocean is the source of a number of novel natural products isolated from the highly diverse and species-rich deep-sea faunal communities (Skropeta, 2008), in particular from those found at hydrothermal vents (Thornburg et al., 2010; Martins et al. 2013). As of 2008, 78 natural products have been isolated from as many as 19 classes and from all Domains of life (Skropeta, 2008). These chemicals show potential for having pharmaceutical properties and applications, including antibiotics (Liu et al., 2013) and anticancer compounds (Wu et al., 2013). Albeit surprising coming from a habitat with no light, even photoprotectives for potential use in sunscreens and cosmetics have been found in deep-sea hydrothermal vent habitats (Martins et al., 2013). While less than $2 \%$ of the marine natural products being explored come from the deep sea (Skropeta, 2013), the potential of novel molecules and genetic pathways within this habitat is vast.

\subsection{Other provisionary services derived from vast size}

The deep sea has long been an environment hosting military activities, allowing for covert transportation and surveillance. Technological advances from deep-sea military operations have led to numerous commercial marine applications in underwater communications, navigation, and propulsion.

As a result of the stability of the deep-sea environment, an additional provisioning service provided by the deep sea is its ability to connect civilizations as well as human infrastructure (e.g., oil and gas derricks with land-based refineries). The first trans-Atlantic cable was laid in 1858 and thus, along with fishing, use of the deep sea as an environment to lay communication cables is among its oldest and most widely used services (Ramirez-Ilondra et al. 2011).

\section{Cultural services}

Cultural services provided by the deep sea are the nonmaterial benefits humans enjoy. These services can range from the valuable scientific knowledge that can be obtained from deep-sea environments, the educational value and the economic benefits generated by science, exploration and discovery (and the technological development that accompanies these), to the more purely aesthetic and inspirational services, including literature, entertainment, ethical considerations, tourism, and spiritual wealth and well-being. The deep-sea's vast expanse has often led to excitement, for example, the discovery of unique habitats, including hydrothermal vents (Corliss et al., 1979), the yeti crabs that live there (Macpherson et al., 2005) and the diversity of life that lives on seamounts and in deep-sea coral habitats (Fig. 1). The mystery and great unknown of the deep-ocean realm provides a nearly endless supply of facts stranger than fiction. As a result, despite the obvious distance and inaccessibility of the deep sea, these environments have pervaded ancient and modern culture to a surprising degree.

Some of the main cultural services provided by the deep sea can be described as educational and scientific, two services that receive significant investment despite today's economic climate. The apparent lack of general public and scientific knowledge on the deep sea stands in contrast to the size of the deep sea and its importance in the Earth's biological and climatic systems. As a result, education management organizations are currently promoting the ocean 
literacy concept, which includes the understanding of the essential principles and fundamental concepts of the ocean, communication about the ocean in a meaningful way and the stewardship involved (Strang and Tran, 2010). One of the roles provided by the deep sea to human culture is in providing a repository of information on past conditions of the planet, stored in the fossil remains of planktonic organisms (e.g., foraminifera, coccolithophores) preserved in deep-marine sediments. This deep-sea paleo-climatological service is of immediate benefit to assessing and predicting current and future climatic effects on our environment and human well-being. For example, foraminifera studies have identified how the ocean temperature has changed over the last 125000 years (Labeyrie et al., 1987). In a similar way, deep-sea environmental conditions are suitable for exceptional preservation of historical cultural artifacts, including ancient Black Sea shipwrecks (Ballard et al., 2001) and potentially much more recent artifacts from polar expeditions (Shackleton's Endurance, Glover et al., 2013).

Although the anthropocentric view of the Earth has mostly revolved around terrestrial environments, references to the deep sea and its importance for humanity can be found throughout history and literature. While the history of the study of deep-sea fauna spans a mere 130 years, references to exploring the deep ocean go much further back. The importance of deep sea cartography in Hellenic civilizations, for instance (Oleson, 2000), illustrates the fascination and exploration potential of the deep ocean dating from several millennia ago. Exploration of the deep ocean has grown vastly since technological advances have allowed easier access to the deep sea. Modern high-resolution deep-water biological investigations are far removed in scope and technology from the first glimpses of deep-sea life recovered in the early 1800 s on sounding casts or from the hand-hauled nets deployed in the 1870s from the sailing vessel HMS Challenger. Scientific advances and the linked exploitation of deep-sea marine resources today elicit significant investment, which drives increasing marine technological development, involving industries that generate substantial economic wealth and extraction of deep-sea resources beneficial to human welfare and development.

With historical exploration and the ensuing fascination with deep-sea life also came inspiration for literature, arts and entertainment, which can all be seen as more purely aesthetic services (Fig. 1). The deep sea has inspired literature since early human civilization. Plato first mentions the myth of the engulfing of Atlantis by the ocean around $360 \mathrm{BC}$. This tradition has continued with novels like 20000 Leagues Under the Sea and Moby Dick. The entertainment value provided by the deep sea is still very much present today, as exemplified by numerous recent documentaries, films and even cartoons (e.g., the BBC documentary Blue Planet - The Deep, the children's program Octonauts, and the Disney/Pixar film Finding Nemo). Another service with aesthetic and entertainment value that benefits from deep-sea func- tions is the growing whale-watching tourist industry, which can provide substantial economic benefits to coastal communities. Growth and aggregation of whales and dolphins depend to a large extent on deep-sea supporting services, such as biomass production over seamounts or water circulation in upwelling areas (Johnston et al., 2008). A newly emerging industry is that of in situ deep-sea tourism, whereby humanoccupied underwater vehicles are being offered to the public to explore deep-water environments in person, an example of a cultural service with exploration and entertainment value that is - for now - only accessible to wealthy individuals. The inspiration and awe that the deep ocean brings us at many different levels of human culture is also present spiritually, with numerous examples mentioned in scripture (e.g., the Bible: Genesis 1:1-3, Proverbs 8:26-28; Quran: 24:40) as well as various indigenous cultures and classical religions displaying important elements of worship and ceremony related to marine mammals (e.g., New Zealand Maoris) and gods representing oceans and seas (the Greek Poseidon). Related to spiritual values are the ethical values that are often assigned to marine life and increasingly to deep-sea animals and environments. Public pressure to conserve deep-sea habitats, such as coral reefs and vents, can be seen as an important contributor to, or the result of the increasing non-use or existential value of, the deep sea (Mengerink et al., 2014).

\section{Discussion}

It is difficult to discuss the deep sea without being waylaid by the severe lack of deep-sea environmental and biological data, the conceptual challenge of its size, and the unexplored habitats (e.g., hadal trenches and vast deep pelagic areas; Ramirez-Ilondra et al. 2011) that likely add heterogeneity and diversity in unknown ways. However, when the current state of knowledge is viewed synoptically, these intellectual shortcomings can be reduced through integration of the diverse chemical, micro- and macro-biological, and environmental information that has been discovered over more than a century of study. What results is a basic understanding of how the temporal and spatial diversity in the deep sea creates a system with far-reaching linkages both within its realm as well as to society as a whole.

\subsection{Temporal and spatial relationships}

Many of the functions provided by the deep sea, even though they occur on small scales in time and space, have direct implications for global services owing to the large size of the environment (Fig. 3). Even regional-scale activities, such as harvesting of deep-sea fish, may have broad temporal and spatial implications for ecosystem services - as these are usually species that are often very long lived (Cailliet et al., 2001) or have either little spatial pattern potentially leading to broad ranges (Haedrich and Merrett, 1990) or ranges 
that reflect a similar distribution to water masses (Koslow, 1993). Even processes thought to proceed at low rates and by bacteria or archaea, such as chemoautotrophy in the pelagic and abyssal seafloor (Nauhaus et al., 2007; Reinthaler et al., 2010; Middelburg, 2011), can have major implications when scaled up to the huge areas and volumes of the deep sea, playing an important role in processes such as energy flow, and carbon sequestration on the global scale.

In addition to the vast nature of the habitat, there can also be a long separation of function and service within the deep sea (Fig. 3). An example of this is that nutrient regeneration, often dominated by microbial activity (Azam et al., 1983), is a feature that occurs so pervasively that its provisioning and regulation of surface production has global application due to the resulting generation of oxygen and foodstuffs. This is even more provocative since in certain instances there are great spatial and temporal distances between function and service; for example, nutrients regenerated in the North Atlantic may not reach surface waters in the North Pacific for millennia. There is even greater separation of service and function for the creation of oil and gas reservoirs. Oil reserves are the result of geological transformation of organic matter buried in deep-ocean sediments (once a biotic entity, but when extracted considered abiotic). Methane hydrate reserves are largely formed through microbially mediated methanogenesis, and although the formation occurs on relatively "rapid" timescales it takes centuries to build up to potentially harvestable concentrations. The same is true of manganese nodules and polymetallic crusts, whose formation takes millions of years, but which even now have yet to provide a service, although they likely will in the very near future.

\subsection{Interrelatedness and threats to ecosystem services and functions}

The biological, physical, and chemical properties of the ecosystem combine to form complex processes that result in globally important services. These supporting, regulating and provisional services are connected both to their functions and to each other in a variety of ways (Fig. 4). In many instances, one function provides a diversity of services; for example, circulation, or more specifically the separation of the deep sea from the atmosphere over long periods of time, provides at least one regulating service and four provisioning services.

The services provided by the deep sea are not impervious to human impacts. The concern as to the susceptibility to overfishing of slow-growing and long-lived species of fish and coral in the deep sea is a topic of debate and concern (Bett, 2001; Morato et al., 2006; Althaus et al., 2009). Climate change itself will impact the functions discussed in the deep sea through ocean acidification, declining oxygen and productivity and increasing temperature (Mora et al., 2013; Levin et al., 2014). These impacts are likely to affect the diversity of the supporting functions discussed here, including biodiversity, nutrient cycling, biomass, and primary and secondary productivity (Jones et al., 2014). While the scale and magnitude of these impacts are difficult to predict, the interrelated nature of the impacts indicates that they will be pervasive in the overall function. For example, the reduced rate of global circulation as a result of human impacts (Bryden et al., 2005) will affect not only many marine systems (Schmittner, 2005), but also the services that are gained from those and deep-sea habitats.

\subsection{Ecosystem services frameworks and the need for integrating deep-sea complexity}

Multiple frameworks have been posed as the initial step to communicate the ecosystem functions and services provided by different habitats. Generally these frameworks or classifications are traditionally centered around terrestrial assessments, partially owing to the limited availability of data and methods to assess the provision of marine and coastal ecosystem services. Other reasons are the low resolution of spatially explicit marine information, the difficulty of quantifying ecosystem functions and processes in the highly dynamic and connected three-dimensional marine environments, and the fact that ecosystem service studies just rarely take marine characteristics into account. It is therefore not surprising that the applications of ecosystem services in marine contexts span a short history (Liquete et al., 2013).

Among the most commonly adopted frameworks is the MA (2005), on which we have largely based our treatise. The most recent general frameworks and classifications have omitted the group of supporting services and the services related to abiotic factors. The MA includes the supporting services category but omits abiotic resources such as minerals, despite its importance for understanding the true extent of deep-sea ecosystem services (Armstrong, 2012). More recently, the CICES (Haines-Young and Potschin, 2013) has been proposed as an update of the MA, and even though it mentions abiotic factors such as abiotic renewables it fails to recognize fossil fuels, and it excludes supporting services. Instead, CICES proposes a "Regulation \& Maintenance" services category (in addition to the provisioning and cultural services). Armstrong et al. (2012) followed the MA, as they argued that there is a myriad of supporting functions that together form important "intermediate" services in the deep sea and that are crucial to other "more final" services. For instance, the remineralization of nutrients is largely a supporting function that feeds into the service of primary production both in situ (i.e., deep-sea chemoautotrophy) and in surface waters, and is critical to the functioning of the global ecosystem. Excluding abiotic factors from ecosystem services is questionable. For instance, it is the abiotic function of $\mathrm{CO}_{2}$ that makes it a greenhouse gas, and one of the main services of the deep sea is its ability to absorb a large proportion of the gas emitted by humans; however, this service is largely due to gas solubility. While abiotic, gas solubility is driven in 

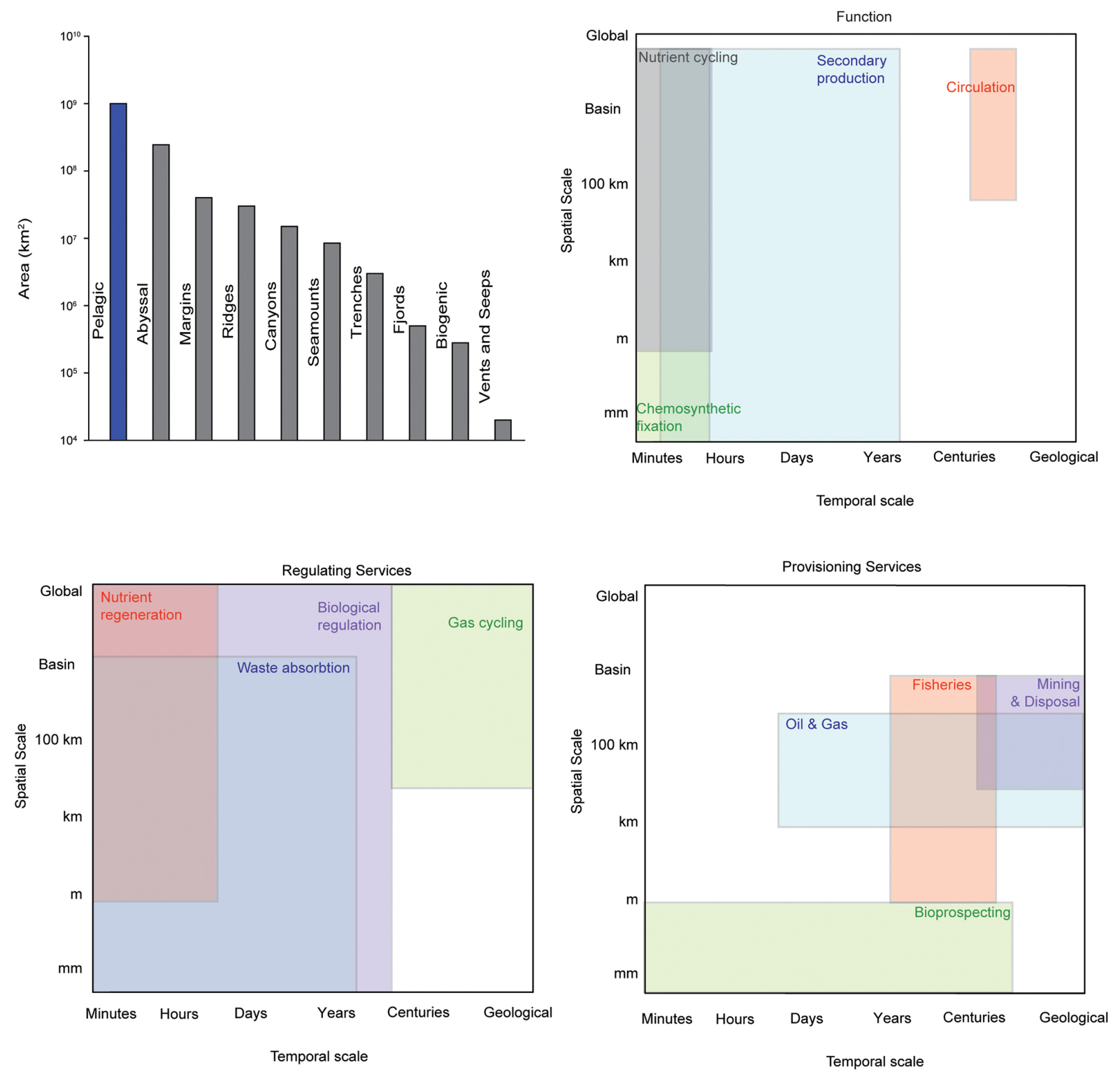

Figure 3. (A) The spatial extent of each of the main deep-sea habitats (pelagic is in $\mathrm{km}^{3}$, while all other habitats are in $\mathrm{km}^{2}$; derived from Ramirez-Llodra et al., 2010.). Note that many of these habitats can be any range of size from small to those depicted. The relationship between spatial and temporal scales for (B) supporting, (C) regulating and (D) provisioning services of the deep sea. Note the log scale in (A) and the approximate scales in (B-D). Geological = thousands to millions of years.

the ocean by temperature, a factor that we are modifying by our release of $\mathrm{CO}_{2}$, leading to a feedback on our climate. As such, the deep sea is an area where the exclusion of abiotic processes and functions in a classification framework would be a disservice to our understanding of deep-sea ecosystem services and the interrelatedness and complexity of the processes and functions involved. Recent efforts by Liquete et al. (2013) produced an adaptation of the CICES framework to cater for marine and coastal ecosystem services, and took into account the classification of the MA (2005), TEEB (2010) and the work of Beaumont et al. (2007). Despite the focus on marine ecosystem services, the adaptation of $\mathrm{Li}$ quete et al. (2013) came up short in addressing the concerns put forward by Armstrong et al. (2012) and Van den Hove and Moreau (2007) about our understanding of the deep sea and the ecosystem services it provides. It is therefore imperative that renewed efforts are undertaken to adapt existing ecosystem services frameworks (Armstrong et al., 2012), or to create new solutions, since defining away unique characteristics of different ecosystems in a uniform system is not desirable. Instead, the challenge in developing multiple appropriately structured classification systems for different 


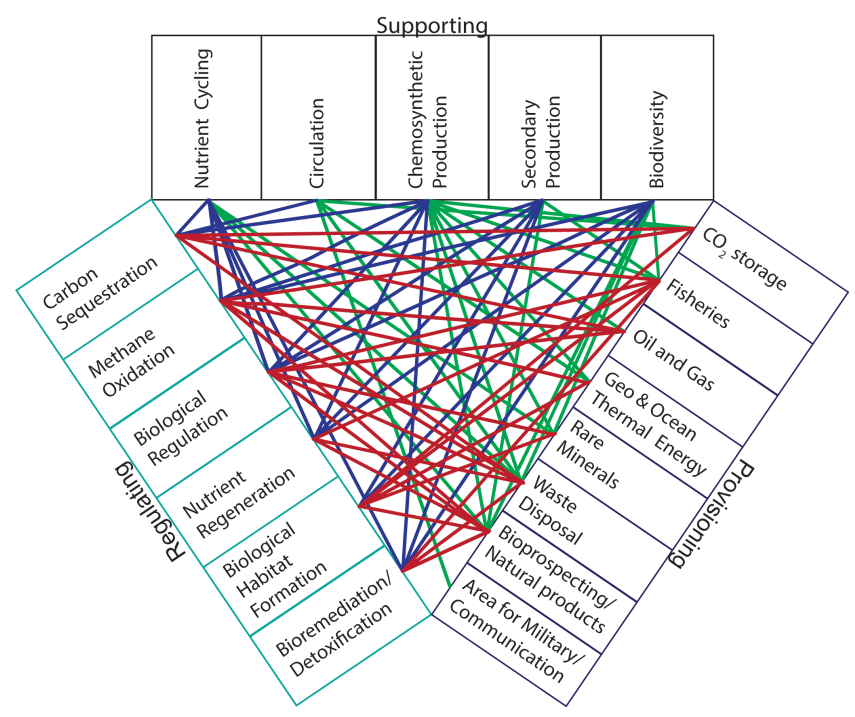

Figure 4. The links between the supporting, provisioning, and regulating services within the deep sea. Color is used to indicate the linkages between each of the different overarching service classes.

purposes presents an opportunity to enrich our thinking about ecosystem services and find appropriate solutions (Costanza, 2008). The current ecosystem service classifications seem incompatible with the needs of the deep-sea realm, its habitats and the ecosystems it contains, and this further makes both the deep sea and the management of it unique. However, a portable framework is essential for management of the deep sea, as the majority of it lies outside of national jurisdiction, meaning that international collaboration is the only means of managing many of its services effectively.

\subsection{Current challenges in function and service evaluation}

While numerous studies have sought to quantify various ecosystem functions in the deep sea (for a review see Smith et al., 2008) and have described the various services provided by the different functions, we know of only one study that has as yet put a monetary value on the extent of ecosystem functions and services in the deep sea (Jobstvogt et al., 2014). However, multiple frameworks have been constructed to facilitate this sort of key analysis (van den Hove and Moreau, 2007; Armstrong et al., 2010, 2012). This lack of knowledge makes ocean management extremely difficult, especially with regards to managing the exploitation of marine resources, as it is presently impossible to know the full "cost" that we will have to pay for exploiting a specific resource. By evaluating ecosystem functions and services provided by the deep sea, we will be able to understand the cost versus benefit of exploitation, which will assist us in making better informed management decisions, as it pertains to the exploitation of deep-sea services.
To understand fully the ecosystem functions provided by the deep sea as a whole, it is important to be able to compare specific functions across a variety of spatial and temporal scales. However, comparisons between studies are often plagued by the fact that different techniques are used. A good example of this is in studies that use different mesh sizes to separate animals by body size, with some separating macrofauna on a 300-micron mesh, while others use a 500-micron mesh. The use of two techniques automatically imposes differences on various properties that relate to ecosystem functioning (e.g., biomass) and services (e.g., biodiversity, productivity), hampering comparisons across ecosystems.

By the very nature of the mechanisms that lead to ecosystem services, a standardized holistic and multidisciplinary approach is necessary for studying it. Collaborations between biogeochemists, physiologists, empirical and observational ecologists who deal with microbes to megafauna in both pelagic and benthic environments, and climate scientists, but also socio-economists are required to understand and further quantify the services provided by the deep sea. However, owing to the pervasive nature of the function of the deep sea, and the threats to it, an important additional link is needed between the stakeholders of the deep sea, which is the global population.

\section{Conclusions}

- The deep sea is the world's largest environment and comprises a multitude of different habitats and a major proportion of the world's species.

- Although over a century of research has been undertaken in the deep sea, our understanding of this environment is limited. However, with the advances we have already made we can begin to understand its role in global energy, nutrients, and biological cycles.

- Services provided by the deep sea are vital to support the current way of life for many humans, providing energy, metal and mineral resources, food and other goods.

- Vast area and long residence times typify deep-sea environments, meaning that even fast processes on small spatial scales create massive services, although in many cases the processes are far removed from their resultant services.

- Many of the functions of the deep sea result in interrelated regulating and provisioning services.

- The stakeholders of the deep sea are not limited to one country or area, but instead consist of the entire global population.

- The deep sea plays an important cultural role, providing inspiration for the arts and having a far-reaching influence even on those that never leave the land. 
- Further research should aim to adapt an existing or to build an appropriate ecosystem services framework that can be applied to the deep sea to quantify its monetary value while creating a more uniform approach to its study.

Acknowledgements. This review was the result of a workshop supported by the International Network for scientific investigation of DEEP-sea ecosystems (INDEEP) through a grant awarded by the Total Foundation. We thank the INDEEP PIs, especially Maria Baker, for making this workshop possible and the International Research Institute of Stavanger for generously hosting the meeting. This manuscript has greatly benefited from comments by three anonymous reviewers and we thank Nicola Beaumont for her advice during the revision of the original manuscript. J. Ingels was supported by a Marie Curie Intra-European Fellowship within the 7th European Community Framework Programme (grant agreement FP7-PEOPLE-2011-IEF no. 300879). A. R. Thurber was supported by National Science Foundation grant 1103428 and LOL provided support throughout the workshop. We declare no competing interests and the funding agency had no input in the content of this manuscript. The order of authorship is reverse alphabetical.

Edited by: T. Treude

\section{References}

Aloisi, G., Bouloubassi, I., Heijs, S. K., Pancost, R. D., Pierre, C., Sinninghe Damsté, J. S., Gottschal, J. C., Forney, L. J., and Rouchy, J.-M.: $\mathrm{CH}_{4}$-consuming microorganisms and the formation of carbonate crusts at cold seeps, Earth Planet. Sc. Lett., 203, 195-203, 2002.

Alonso-Sáez, L., Galand, P. E., Casamayor, E. O., Pedrós-Alió, C., and Bertilsson, S.: High bicarbonate assimilation in the dark by Arctic bacteria, ISME J., 4, 1581-1590, 2010.

Alonso-Sáez, L., Waller, A. S., Mende, D. R., Bakker, K., Farnelid, H., Yager, P.L., Lovejoy, C., Tremblay, J.-E., Potvin, M., Heinrich, F., Estrada, M., Riemann, L., Bork, P., Pedrós-Alió, C., and Bertilsson, S.: Role for urea in nitrification by polar marine Archaea, P. Natl. Acad. Sci., 109, 17989-17994, 2012.

Althaus, F., Williams, A., Schlacher, T. A., Kloser, R. J., Green, M. A., Barker, B. A., Bax, N. J., Brodie, P., and SchlacherHoenlinger, M. A.: Impacts of bottom trawling on deep-coral ecosystems of seamounts are long-lasting, Mar. Ecol.-Prog. Ser., 397, 40, 2009.

Anantharaman, K., Breier, J. A., Sheik, C. S., and Dick, G. J.: Evidence for hydrogen oxidation and metabolic plasticity in widespread deep-sea sulfur-oxidizing bacteria, P. Natl. Acad. Sci., 110, 330-335, 2013.

Armstrong, C. W., Foley, N., Tinch, R., and Hove, S. v. d.: Ecosystem Goods and Services of the Deep Sea, HERMIONE (Hotspot Ecosystem Research and Man's impact on European Seas), Deliverable D6.2: Ecosystem Goods and Services of the Deep Sea, WP6: Socioeconomics, Ocean Governance and Science-Policy Interfaces, 2010.
Armstrong, C. W., Foley, N. S., Tinch, R., and van den Hove, S.: Services from the deep: Steps towards valuation of deep sea goods and services, Ecosyst. Serv., 2, 2-13, 2012.

Azam, F., Fenchel, T., Field, J. G., Gray, J. S., Meyer-Reil, L. A., and Thingstad, F.: The ecological role of water-column microbes in the sea, Mar. Ecol.-Prog. Ser., 10, 257-263, 1983.

Bailey, D. M., Collins, M. A., Gordon, J. D. M., Zuur, A. F., and Priede, I. G.: Long-term changes in deep-water fish populations in the northeast Atlantic: a deeper reaching effect of fisheries?, P. R. Soc. B, 276, 1965-1969, 2009.

Ballard, R. D., Hiebert, F. T., Coleman, D. F., Ward, C., Smith, J. S., Willis, K., Foley, B., Croff, K., Major, C., and Torre, F.: Deepwater archaeology of the black sea: the 2000 season at Sinop, Turkey, Am. J. Archaeol., 105, 607-623, 2001.

Beaumont, N. J., Austen, M. C., Atkins, J. P., Burdon, D., Degraer, S., Dentinho, T. P., Derous, S., Holm, P., Horton, T., van Ierland, E., Marboe, A. H., Starkey, D. J., Townsend, M., and Zarzycki, T.: Identification, definition and quantification of goods and services provided by marine biodiversity: Implications for the ecosystem approach, Mar. Pollut. Bull., 54, 253-265, 2007.

Benn, A. R., Weaver, P. P., Billet, D. S. M., van den Hove, S., Murdock, A. P., Doneghan, G. B., and Le Bas, T.: Human Activities on the Deep Seafloor in the North East Atlantic: An Assessment of Spatial Extent, PLoS ONE, 5, e12730, doi:10.1371/journal.pone.0012730, 2010.

Bernardino, A. F., Smith, C. R., Baco, A., Altamira, I., and Sumida, P. Y. G.: Macrofaunal succession in sediments around kelp and wood falls in the deep NE Pacific and community overlap with other reducing habitats, Deep-Sea Res. Pt. I, 57, 708-723, 2010.

Berner, R. A.: Biogeochemical cycles of carbon and sulfur and their effect on atmospheric oxygen over phanerozoic time, Palaeogeogr. Palaeocl., 75, 97-122, 1989.

Bernhard, J. M., Barry, J. P., Buck, K. R., and Starczak, V. R.: Impact of intentionally injected carbon dioxide hydrate on deep-sea benthic foraminiferal survival, Glob. Change Biol., 15, 20782088, 2009.

Bett, B. J.: UK Atlantic Margin Environmental Survey: introduction and overview of bathyal benthic ecology, Cont. Shelf Res., 21, 917-956, 2001.

Biastoch, A., Treude, T., Rüpke, L. H., Riebesell, U., Roth, C., Burwicz, E. B., Park, W., Latif, M., Böning, C. W., and Madec, G.: Rising Arctic Ocean temperatures cause gas hydrate destabilization and ocean acidification, Geophys. Res. Lett., 38, L08602, doi:10.1029/2011GL047222, 2011.

Billett, D. S. M., Bett, B. J., Reid, W. D. K., Boorman, B., and Priede, I. G.: Long-term change in the abyssal NE Atlantic: The "Amperima Event" revisited, Deep-Sea Res. Pt. II, 57, 14061417, 2010.

Boetius, A. and Suess, E.: Hydrate Ridge: a natural laboratory for the study of microbial life fueled by methane from near-surface gas hydrates, Chem. Geol., 205, 291-310, doi:10.1016/j.chemgeo.2003.12.034, 2004.

Boetius, A. and Wenzhöfer, F.: Seafloor oxygen consumption fuelled by methane from cold seeps, Nat. Geosci., 6, 725-734, 2013.

Bowden, D. A., Schiaparelli, S., Clark, M. R., and Rickard, G. J.: A lost world? Archaic crinoid-dominated assemblages on an Antarctic seamount, Deep-Sea Res. Pt. II, 58, 119-127, 2011. 
Braeckman, U., Provoost, P., Moens, T., Soetaert, K., Middelburg, J. J., Vincx, M. and Vanaverbeke, J.: Biological vs. physical mixing effects on benthic food web dynamics, PLoS ONE, 6, e18078, doi:10.1371/journal.pone.0018078, 2011.

Bronk, D. A.: Dynamics of DON, in: Biogeochemistry of Marine Dissolved Organic Matter, edited by: Hansell, D. A. and Carlson, C. A., Academic Press, San Diego, 153-247, 2002.

Bryden, H. L., Longworth, H. R., and Cunningham, S. A.: Slowing of the Atlantic meridional overturning circulation at $25^{\circ} \mathrm{N}$, Nature, 438, 655-657, 2005.

Buesseler, K. O., Lamborg, C. H., Boyd, P. W., Lam, P. J., Trull, T. W., Bidigare, R. R., Bishop, J. K. B., Casciotti, K. L., Dehairs, F., Elskens, M., Honda, M., Karl, D. M., Siegel, D. A., Silver, M. W., Steinberg, D. K., Valdes, J., Mooy, B. V., and Wilson, S.: Revisiting carbon flux through the ocean's twilight zone, Science, 316, 567-570, 2007.

Burd, A. B., Hansell, D. A., Steinberg, D. K., Anderson, T. R., Arístegui, J., Baltar, F., Beaupré, S. R., Buesseler, K. O., DeHairs, F., Jackson, G. A., Kadko, D. C., Koppelmann, R., Lampitt, R. S., Nagata, T., Reinthaler, T., Robinson, C., Robison, B. H., Tamburini, C., and Tanaka, T.: Assessing the apparent imbalance between geochemical and biochemical indicators of meso- and bathypelagic biological activity: What the @\$\#! is wrong with present calculations of carbon budgets?, Deep-Sea Res. Pt. II, 57, 1557-1571, 2010.

Cailliet, G., Andrews, A., Burton, E., Watters, D., Kline, D., and Ferry-Graham, L.: Age determination and validation studies of marine fishes: do deep-dwellers live longer?, Exp. Gerontol., 36, 739-764, 2001.

Canadell, J. G., Quéré, C. L., Raupach, M. R., Field, C. B., Buitenhuis, E. T., Ciais, P., Conway, T. J., Gillett, N. P., Houghton, R. A., and Marland, G.: Contributions to accelerating atmospheric $\mathrm{CO}_{2}$ growth from economic activity, carbon intensity, and efficiency of natural sinks, P. Natl. Acad. Sci., 104, 18866-18870, 2007.

Canals, M., Puig, P., de Madron, X. D., Heussner, S., Palanques, A., and Fabres, J.: Flushing submarine canyons, Nature, 444, 354 357, 2006

Chivers, A. J., Narayanaswamy, B. E., Lamont, P. A., Dale, A., and Turnewitsch, R.: Changes in polychaete standing stock and diversity on the northern side of Senghor Seamount (NE Atlantic), Biogeosciences, 10, 3535-3546, doi:10.5194/bg-10-3535-2013, 2013.

Clark, M. R. and Koslow, J. A.: Impacts of Fisheries on Seamounts, in: Seamounts: Ecology, Fisheries \& Conservation, edited by: Pitcher, T. J., Morato, T., Hart, P. J. B., Clark, M. R., Haggan, N., and Santos, R. S., Blackwell Publishing Ltd, Oxford, Uk, doi:10.1002/9780470691953.ch19, 2008.

Clark, M. R., Rowden, A. A., Schlacher, T., Williams, A., Consalvey, M., Stocks, K. I., Rogers, A. D., O’Hara, T. D., White, M., Shank, T. M., and Hall-Spencer, J. M.: The Ecology of Seamounts: Structure, Function, and Human Impacts, Annu. Rev. Mar. Sci., 2, 253-278, 2010.

Codispoti, L. A., Brandes, J. A., Christensen, J. P., Devol, A. H., Naqvi, S. W. A., Paerl, H. W., and Yoshinari, T.: The oceanic fixed nitrogen and nitrous oxide budgets: Moving targets as we enter the anthropocene?, Sci. Mar., 65, 85-105, 2001.

Cordes, E. E., McGinley, M. P., Podowski, E. L., Becker, E. L., Lessard-Pilon, S., Viada, S. T., and Fisher, C. R.: Coral com- munities of the deep Gulf of Mexico, Deep-Sea Res. Pt. I, 55, 777-787, 2008.

Cordes, E. E., Becker, E. L., Hourdez, S., and Fisher, C. R.: Influence of foundation species, depth, and location on diversity and community composition at Gulf of Mexico lower-slope cold seeps, Deep-Sea Res. Pt. II, 57, 1870-1881, 2010a.

Cordes, E. E., Cunha, M. R., Galéron, J., Mora, C., Olu-Le Roy, K., Sibuet, M., Van Gaever, S., Vanreusel, A., and Levin, L. A.: The influence of geological, geochemical, and biogenic habitat heterogeneity on seep biodiversity, Mar. Ecol., 31, 51-65, 2010b.

Corliss, J. B., Dymond, J., Gordon, L. I., Edmond, J. M., Herzen, R. P. von, Ballard, R. D., Green, K., Williams, D., Bainbridge, A., Crane, K., and van Andel, T. H.: Submarine Thermal Sprirngs on the Galápagos Rift, Science, 203, 1073-1083, doi:10.1126/science.203.4385.1073, 1979.

Costanza, R.: Ecosystem services: Multiple classification systems are needed, Biol. Conserv., 141, 350-352, 2008.

Cowie, G. L., Calvert, S. E., Pedersen, T. F., Schulz, H., and von Rad, U.: Organic content and preservational controls in surficial shelf and slope sediments from the Arabian Sea (Pakistan margin), Mar. Geol., 161, 23-38, 1999.

Cullen, D. J.: Distribution composition and age of submarine phosphorites on Chatham Rise east of New Zealand, SEPM Special Publication 29, 139-148, 1980.

Dachs, J., Lohmann, R., Ockenden, W. A., Méjanelle, L., Eisenreich, S. J., and Jones, K. C.: Oceanic biogeochemical controls on global dynamics of persistent organic pollutants, Environ. Sci. Technol., 36, 4229-4237, 2002.

Danovaro, R.: Extending the approaches of biodiversity and ecosystem functioning to the deep ocean, in: Marine Biodiversity and Ecosystem Functioning: Frameworks, methodologies, and integration, edited by: Solan, M., Aspden, R. J., and Paterson, D. M., Oxford University Press, Oxford, 115-126, 2012.

Danovaro, R., Dell'Anno, A., Corinaldesi, C., Magagnini, M., Noble, R., Tamburini, C., and Weinbauer, M.: Major viral impact on the functioning of benthic deep-sea ecosystems, Nature, 454, 1084-1087, 2008a.

Danovaro, R., Gambi, C., Dell'Anno, A., Corinaldesi, C., Fraschetti, S., Vanreusel, A., Vincx, M., and Gooday, A. J.: Exponential decline of deep-sea ecosystem functioning linked to benthic biodiversity loss, Curr. Biol., 18, 1-8, $2008 \mathrm{~b}$.

De Angelis, M. A., Lilley, M. D., and Baross, J. A.: Methane oxidation in deep-sea hydrothermal plumes of the endeavour segment of the Juan de Fuca Ridge, Deep-Sea Res. Pt. I, 40, 1169-1186, doi:10.1016/0967-0637(93)90132-M, 1993.

De Leo, F. C., Smith, C. R., Rowden, A. A., Bowden, D. A., and Clark, M. R.: Submarine canyons: hotspots of benthic biomass and productivity in the deep sea, P. R. Soc. B, 277, 2783-2792, 2010.

De Leo, F. C., Vetter, E. W., Smith, C. R., Rowden, A. A., and McGranaghan, M.: Spatial scale-dependent habitat heterogeneity influences submarine canyon macrofaunal abundance and diversity off the Main and Northwest Hawaiian Islands, Deep-Sea Res. Pt II, 104, 267-290, doi:10.1016/j.dsr2.2013.06.015, 2013.

De Stigter, H. C., Boer, W., de Jesus Mendes, P. A., Jesus, C. C., Thomsen, L., van den Bergh, G. D., and van Weering, T. C. E.: Recent sediment transport and deposition in the Nazaré Canyon, Portuguese continental margin, Mar. Geol., 246, 144-164, 2007. 
Dick, G. J., Anantharaman, K., Baker, B. J., Li, M., Reed, D. C., and Sheik, C. S.: The microbiology of deep-sea hydrothermal vent plumes: ecological and biogeographic linkages to seafloor and water column habitats, Front. Microbiol., 4, 124, doi:10.3389/fmicb.2013.00124, 2013.

Dylan, T.: Ocean thermal energy conversion: current overview and future outlook, Renew. Energy, 6, 367-373, 1995.

Flothmann, S., von Kistowski, K., Dolan, E., Lee, E., Meere, F., and Album, G.: Closing loopholes: getting illegal fishing under control, Science, 328, 1235-1236, 2010.

Foley, N. and Armstrong, C. W.: The ecological and economic value of cold-water coral ecosystems, Ocean Coast. Manage., 53, 313326, 2010.

Francis, C. A., Beman, J. M., and Kuypers, M. M. M.: New processes and players in the nitrogen cycle: the microbial ecology of anaerobic and archaeal ammonia oxidation, ISME J., 1, 1927, 2007.

Froescheis, O., Looser, R., Cailliet, G. M., Jarman, W. M., and Ballschmiter, K.: The deep-sea as a final global sink of semivolatile persistent organic pollutants? Part I: PCBs in surface and deep-sea dwelling fish of the North and South Atlantic and the Monterey Bay Canyon (California), Chemosphere, 40, 651-660, 2000.

Gage, J. D. and Tyler, P. A.: Deep-sea biology: a natural history of organisms at the deep-sea floor, Cambridge University Press, 1991.

Gebruk, A. V., Chevaldonné, P., Shank, T., Lutz, R. A., and Vrijenhoek, R. C.: Deep-sea hydrothermal vent communities of the Logatchev area $\left(14^{\circ} 45^{\prime} \mathrm{N}\right.$, Mid-Atlantic Ridge): Diverse biotopes and high biomass, J. Mar. Biol. Assoc. UK, 80, 383-393, 2000.

Glover, A. G. and Smith, C. R.: The deep-sea floor ecosystem: current status and prospects of anthropogenic change by the year 2025, Environ. Conserv., 30, 219-241, 2003.

Glover, A. G., Wiklund, H., Taboada, S., Avila, C., Cristobo, J., Smith, C. R., Kemp, K. M., Jamieson, A. J., and Dahlgren, T. G.: Bone-eating worms from the Antarctic: the contrasting fate of whale and wood remains on the Southern Ocean seafloor, P. R. Soc. B, 280, 1768, doi:10.1098/rspb.2013.1390, 2013.

Grassle, J. F. and Maciolek, N. J.: Deep-sea species richness: regional and local diversity estimates from quantitative bottom samples, Am. Natural., 139, 313-341, 1992.

Gruber, N. and Sarmiento, J. L.: Global patterns of marine nitrogen fixation and denitrification, Global Biogeochem. Cy., 11, 235266, 1997.

Gutt, J. and Starmans, A.: Structure and biodiversity of megabenthos in the Weddell and Lazarev Seas (Antarctica): Ecological role of physical parameters and biological interactions, Polar Biol., 20, 229-247, 1998.

Haedrich, R. L. and Merrett, N. R.: Little evidence for faunal zonation or communities in deep sea demersal fish faunas, Progr. Oceanogr., 24, 239-250, 1990.

Haines-Young, R. and Potschin, M.: Common International Classification of Ecosystem Services (CICES): Consultation on Version 4, August-December 2012, 2013.

Hansell, D. A., Carlson, C. A., and Schlitzer, R.: Net removal of major marine dissolved organic carbon fractions in the subsurface ocean: Removal of exported DOC, Global Biogeochem. Cy., 26, GB1016, doi:10.1029/2011GB004069, 2012.
Hansman, R. L., Griffin, S., Watson, J. T., Druffel, E. R., Ingalls, A. E., Pearson, A., and Aluwihare, L. I.: The radiocarbon signature of microorganisms in the mesopelagic ocean, P. Natl. Acad. Sci., 106, 6513-6518, 2009.

Harris, P. T., Mamillan-Lawler, M., Rupp, J., and Baker, E. K.: Geomorphology of the oceans, Mar. Geol., 352, 4-24, doi:10.1016/j.margeo.2014.01.011, 2014.

Hasemann, C. and Soltwedel, T.: Small-scale heterogeneity in deepsea nematode communities around biogenic structures, PLoS One 6, e29152, doi:10.1371/journal.pone.0029152, 2011.

Hawaii Undersea Military Munitions Assessment (HUMMA) - Final Investigation Report (No. HI-05): University of Hawaii at Manoa, Environet, Inc., 2010.

Hein, J. R., Mizell, K., Koschinsky, A., and Conrad, T. A.: Deepocean mineral deposits as a source of critical metals for highand green-technology applications: Comparison with land-based resources, Ore Geol. Rev., 51, 1-14, 2013..

Herndl, G. J. and Reinthaler, T.: Microbial control of the dark end of the biological pump, Nat. Geosci., 6, 718-724, 2013.

Herndl, G. J., Reinthaler, T., Teira, E., van Aken, H., Veth, C., Pernthaler, A., and Pernthaler, J.: Contribution of Archaea to total prokaryotic production in the deep Atlantic Ocean, Appl. Environ. Microbiol., 71, 2303-2309, 2005.

Herzig, P. M. and Hannington, M. D.: Polymetallic massive sulfides at the modern seafloor a review, Ore Geol. Rev., 10, 95-115, 1995.

Hessler, R. R. and Sanders, H. L.: Faunal diversity in the deep-sea, Deep-Sea Res., 14, 65-78, 1967.

Howell, K. L., Pond, D. W., Billett, D. S., and Tyler, P. A.: Feeding ecology of deep-sea seastars (Echinodermata: Asteroidea): a fatty-acid biomarker approach, Mar. Ecol.-Prog. Ser., 255, 193206, 2003.

Hughes, D. J., Brown, L., Cook, G. T., Cowie, G., Gage, J. D., Good, E., Kennedy, H., MacKenzie, A. B., Papadimitriou, S., and Shimmield, G. B.: The effects of megafaunal burrows on radiotracer profiles and organic composition in deep-sea sediments: preliminary results from two sites in the bathyal north-east Atlantic, Deep-Sea Res. Pt. I, 52, 1-13, 2005.

Hunter, W. R., Veuger, B. and Witte, U.: Macrofauna regulate heterotrophic bacterial carbon and nitrogen incorporation in lowoxygen sediments, ISME J, 6, 2140-2151, 2012.

Ingalls, A. E., Shah, S. R., Hansman, R. L., Aluwihare, L. I., Santos, G. M., Druffel, E. R., and Pearson, A.: Quantifying archaeal community autotrophy in the mesopelagic ocean using natural radiocarbon, P. Natl. Acad. Sci., 103, 6442-6447, 2006.

Ingels, J., Van den Driessche, P., De Mesel, I., Vanhove, S., Moens, T., and Vanreusel, A.: Preferred use of bacteria over phytoplankton by deep-sea nematodes in polar regions, Mar. Ecol.-Prog. Ser., 406, 121-133, 2010.

Intergovernmental Panel on Climate Change (IPCC), Climate Change 2007: The Physical Science Basis, Contribution of Working Group I to the Fourth Assessment Report of the Intergovernmental Panel on Climate Change, edited by: Solomon, S., Qin, D., Manning, M., Chen, Z., Marquis, M., Averyt, K. B., Tignor, M., and Miller, H. L., Cambridge Univ. Press, Cambridge, UK, 2007.

Jahnke, R. A.: The global ocean flux of particulate organic carbon: Areal distribution and magnitude, Global Biogeochem. Cy., 10, 71-88, 1996. 
Jobstvogt, N., Hanley, N., Hynes, S., Kenter, J., and Witte, U.: Twenty thousand sterling under the sea: Estimating the value of protecting deep-sea biodiversity, Ecol. Econ., 97, 10-19, 2014.

Johnston, D. W., McDonald, M., Polovina, J., Domokos, R., Wiggins, S., and Hildebrand, J.: Temporal patterns in the acoustic signals of beaked whales at Cross Seamount, Biol. Lett., 4, 208211, 2008.

Jones, D. O. B., Yool, A., Wei, C.-L., Henson, S. A., Ruhl, H. A., Watson, R. A., and Gehlen, M.: Global reductions in seafloor biomass in response to climate change, Glob. Change Biol., 20, 1861-1872, doi:10.1111/gcb.12480, 2014.

Judd, A. G., Hovland, M., Dimitrov, L. I., Garcia Gil, S., and Jukes, V.: The geological methane budget at continental margins and its influence on climate change, Geofluids, 2, 109-126, 2002.

Kato, Y., Fujinaga, K., Nakamura, K., Takaya, Y., Kitamura, K., Ohta, J., Toda, R., Nakashima, T., and Iwamori, H.: Deep-sea mud in the Pacific Ocean as a potential resource for rare-earth elements, Nat. Geosci, 4, 535-539, 2011.

Kemp, D. B., Coe, A. L., Cohen, A. S., and Schwark, L.: Astronomical pacing of methane release in the Early Jurassic period, Nature, 437, 396-399, 2005.

Kiriakoulakis, K., Stutt, E., Rowland, S. J., Annick, V., Lampitt, R. S., and Wolff, G. A.: Controls on the organic chemical composition of settling particles in the Northeast Atlantic Ocean, Progr. Oceanogr., 50, 65-87, 2001.

Klauda, J. B. and Sandler, S. I.; Global distribution of methane hydrate in ocean sediment, Energ. Fuels, 19, 459-470, 2005.

Klitgaard, A. B. and Tendal, O. S. Distribution and species composition of mass occurrences of large-sized sponges in the northeast Atlantic, Progr. Oceanogr., 61, 57-98, 2004.

Knight, H.: 20,000 megawatts under the sea: Oceanic steam engines. In: New Scientist, 1 March 2014, 48-51, available at: http://www.newscientist.com/article/mg22129580. 900-20000-megawatts-under-the-sea-oceanic-steam-engines. html, (last access: 3 March 2014), 2014.

Knittel, K. and Boetius, A.: Anaerobic Oxidation of Methane: Progress with an Unknown Process, Annu. Rev. Microbiol., 63, 311-334, 2009.

Koslow, J. A.: Community structure in North Atlantic deep-sea fishes, Progr. Oceanogr., 31, 321-338, 1993.

Kube, M., Chernikova, T. N., Al-Ramahi, Y., Beloqui, A., LopezCortez, N., Guazzaroni, M. E., Heipieper, H. J., Klages, S., Kotsyrbenko, O. R., Langer, I., Nechitaylo, T. Y., Lünsdorf, H., Fernández, M., Juárez, S., Ciordia, S., Singer, S., Kagan, O., Egorova, O., Petit, P. A., Stogios, P., Kim, Y., Tchigvintsev, A., Flick, R., Denaro, R., Genovese, M., Albar, J. P., Reva, O. N., Martínez-Gomariz, M., Tran, H., Ferrer, M., Savchenko, A., Yakunin, A. F., Yakimov, M. M., Golyshina, O. V., Reinhardt, R., and Golyshin, P. N.: Genome sequence and functional genomic analysis of the oil-degrading bacterium Oleispira antarctica, Nat. Commun., 4, 2156, doi:10.1038/ncomms3156, 2013.

Kvassnes, A. J. S. and Iversen, E.: Waste sites from mines in Norwegian Fjords, Mineralproduksjon., 3, A27-A38, 2013.

Kvenvolden, K. A.: Gas hydrates-geological perspective and global change, Rev. Geoph., 31, 173-187, 1993.

Labeyrie, L. D., Duplessy, J. C., and Blanc, P. L.: Variations in mode of formation and temperature of oceanic deep waters over the past 125,000 years, Nature, 327, 477-482, doi:10.1038/327477a0, 1987.
Lam, P. and Kuypers, M. M. M.: Microbial nitrogen cycling processes in oxygen minimum zones, Annu. Rev. Mar. Sci., 3, 317 345, 2011.

Laverock, B., Gilbert, J., Tait, K., Osborn, A. M., and Widdicombe, S.: Bioturbation: impact on the marine nitrogen cycle, Biochem. Soc. Trans., 39, 315-320, doi:10.1042/BST0390315, 2011.

Leduc, D., Rowden, A. A., Bowden, D. A., Probert, P. K., Pilditch, C. A., and Nodder, S. D.: Unimodal relationship between biomass and species richness of deep-sea nematodes: implications for the link between productivity and diversity, Mar. Ecol.Prog. Ser., 454, 53-64, doi:10.3354/meps09609, 2012.

Lessard-Pilon, S. A., Podowski, E. L., Cordes, E. E., and Fisher, C. R.: Megafauna community composition associated with Lophelia pertusa colonies in the Gulf of Mexico, Deep-Sea Res. Pt. II, 57, 1882-1890, 2010.

Levin, L. A.: Interactions between metazoans and large, agglutinating protozoans: implications for the community structure of deep-sea benthos, Am. Zool., 31, 886-900, 1991.

Levin, L. A.: Oxygen minimum zone benthos: adaptation and community response to hypoxia, Oceanogr. Mar. Biol., 41, 1-45, 2003.

Levin, L. A. and Dayton, P. K.: Ecological theory and continental margins: Where shallow meets deep, Trends Ecol. Evol., 24, 606-617, 2009.

Levin, L. A. and Michener, R. H.: Isotopic evidence for chemosynthesis-based nutrition of macrobenthos: the lightness of being at Pacific methane seeps, Limnol. Oceanogr., 47, 13361345, 2002.

Levin, L., Blair, N., DeMaster, D., Plaia, G., Fornes, W., Martin, C., and Thomas, C.: Rapid subduction of organic matter by maldanid polychaetes on the North Carolina slope, J. Mar. Res., 55, 595611, 1997.

Levin, L. A., James, D. W., Martin, C. M., Rathburn, A. E., Harris, L. H., and Michener, R. H.: Do methane seeps support distinct macrofaunal assemblages? Observations on community structure and nutrition from the northern California slope and shelf, Mar. Ecol.-Prog. Ser., 208, 21-39, 2000.

Levin, L. A., Etter, R. J., Rex, M. A., Gooday, A. J., Smith, C. R., Pineda, J., Stuart, C. T., Hessler, R. R., and Pawson, D.: Environmental influences on regional deep-sea species diversity, Annu. Rev. Ecol. Sys., 32, 51-93, 2001.

Levin, L. A., Mendoza, G. F., Gonzalez, J. P., Thurber, A. R., and Cordes, E. E.: Diversity of bathyal macrofauna on the Northeastern Pacific Margin: the influence of methane seeps and oxygen minimum zones, Mar. Ecol., 31, 94-110, 2010.

Levin, L. A., Liu, K.-K., Emeis, K.-C., Breitburg, D.L., Cloern, J., Deutsch, C., Giani, M., Goffart, A., Hofmann, E. E., Lachkar, Z., Limburg, K., Liu, S.-M., Montes, E., Naqvi, W., Ragueneau, O., Rabouille, C., Sarkar, S. K., Swaney, D. P., Wassman, P., and Wishner, K. F.: Comparative biogeochemistry-ecosystem-human interactions on dynamic continental margins, J. Mar. Syst., in press, doi:10.1016/j.jmarsys.2014.04.016, 2014.

Liquete, C., Piroddi, C., Drakou, E. G., Gurney, L., Katsanevakis, S., Charef, A., and Egoh, B.: Current Status and Future Prospects for the Assessment of Marine and Coastal Ecosystem Services: A Systematic Review, Plos One, 8, e67737, doi:10.1371/journal.pone.0067737, 2013.

Liu, N., Shang, F., Xi, L., and Huang, Y.: Tetroazolemycins A and B, Two New Oxazole-Thiazole Siderophores from Deep-Sea 
Streptomyces olivaceus FXJ8.012, Mar. Drugs, 11, 1524-1533, doi:10.3390/md11051524, 2013.

Longhurst, A. R.: Role of the marine biosphere in the global carbon cycle, Limnol. Oceanogr., 36, 1507-1526, 1991.

Looser, R., Froescheis, O., Cailliet, G. M., Jarman, W. M., and Ballschmiter, K.: The deep-sea as a final global sink of semivolatile persistent organic pollutants? Part II: Organochlorine pesticides in surface and deep-sea dwelling fish of the North and South Atlantic and the Monterey Bay Canyon (California), Chemosphere, 40, 661-670, 2000.

Loreau, M.: Biodiversity and ecosystem functioning: the mystery of the deep sea, Curr. Biol., 18, R126-R128, 2008.

Loreau, M., Naeem, S., Inchausti, P., Bengtsson, J., Grime, J. P., Hector, A., Hooper, D. U., Huston, M. A., Raffaelli, D., Schmid, B., Tilman, D., and Wardle, D. A.: Biodiversity and ecosystem functioning: current knowledge and future challenges, Science, 294, 804-808, 2001.

Lu, Z., Deng, Y., Van Nostrand, J. D., He, Z., Voordeckers, J., Zhou, A., Lee, Y.-J., Mason, O. U., Dubinsky, E. A., Chavarria, K. L., Tom, L. M., Fortney, J. L., Lamendella, R., Jansson, J. K., D'haeseleer, P., Hazen, T. C., and Zhou, J.: Microbial gene functions enriched in the Deepwater Horizon deep-sea oil plume, ISME J., 6, 451-460, 2012.

Lutz, M. J., Caldeira, K., Dunbar, R. B., and Behrenfeld, M. J.: Seasonal rhythms of net primary production and particulate organic carbon flux to depth describe the efficiency of biological pump in the global ocean, J. Geophys. Res.-Oceans, 112, C10011, doi:10.1029/2006JC003706, 2007.

Mace, G., Bateman, I. J., Albon, S., Balmford, A., Church, A., and Winn, J.: Conceptual framework and methodology, Report to the UK National Ecosystem Assessment, 2009.

Macpherson, E., Jones, W., and Segonzac, M.: A new squat lobster family of Galatheoidea (Crustacea, Decapoda: Anomura) from the hydrothermal vents of the Pacific-Antarctic Ridge, Zoosystema, 27, 709-723, 2005.

Martin, J. H., Knauer, G. A., Karl, D. M., and Broenkow, W. W.: VERTEX: Carbon cycling in the northeast Pacific, Deep-Sea Res., 34, 267-285, 1987.

Martins, A., Tenreiro, T., Andrade, G., Gadanho, M., Chaves, S., Abrantes, M., Calado, P., Tenreiro, R., and Vieira, H.: Photoprotective Bioactivity Present in a Unique Marine Bacteria Collection from Portuguese Deep Sea Hydrothermal Vents, Mar. Drugs, 11, 1506-1523, doi:10.3390/md11051506, 2013.

McLeod, R. J. and Wing, S. R.: Hagfish in the New Zealand Fjords are supported by chemoautotrophy of forest carbon, Ecology, 88, 809-816, 2007.

McLeod, R. J. and Wing, S. R.: Strong pathways for incorporation of terrestrially derived organic matter into benthic communities, Estuar. Coast. Shelf Sci., 82, 645-653, 2009.

Mengerink, K. J., Van Dover, C. L., Ardron, J., Baker, M., EscobarBriones, E., Gjerde, K., Koslow, J. A., Ramirez-Llodra, E., LaraLopez, A., Squires, D., Sweetman, A. K., and Levin, L. A.: A call for deep-ocean stewardship, Science, 344, 696-698, 2014.

Middelburg, J. J.: Chemoautotrophy in the ocean, Geophys. Res. Lett., 38, 2011.

Millennium assessment Ecosystem Assessment: Ecosystems and Human Well-being: Synthesis, Millennium Ecosystem Assessment, Island Press, Washington DC, 2005.
Miller, R. J., Hocevar, J., Stone, R. P., and Fedorov, D. V.: Structure-forming corals and sponges and their use as fish habitat in bering sea submarine canyons, PLoS ONE 7, e33885, doi:10.1371/journal.pone.0033885, 2012.

Montagna, P. A., Baguley, J. G., Cooksey, C., Hartwell, I., Hyde, L. J., Hyland, J. L., Kalke, R. D., Kracker, L. M., Reuscher, M., and Rhodes, A. C.: Deep-Sea Benthic Footprint of the Deepwater Horizon Blowout, PloS ONE, 8, e70540, doi:10.1371/journal.pone.0070540, 2013.

Mora, C., Tittensor, D. P., Adl, S., Simpson, A. G. B., and Worm, B. How Many Species Are There on Earth and in the Ocean?, PLoS Biol., 9, e1001127, doi:10.1371/journal.pbio.1001127, 2011.

Mora, C., Wei, C.-L., Rollo, A., Amaro, T., Baco, A. R., Billett, D., Bopp, L., Chen, Q., Collier, M., Danovaro, R., Gooday, A. J., Grupe, B. M., Halloran, P. R., Ingels, J., Jones, D. O. B., Levin, L. A., Nakano, H., Norling, K., Ramirez-Llodra, E., Rex, M., Ruhl, H. A., Smith, C. R., Sweetman, A. K., Thurber, A. R., Tjiputra, J. F., Usseglio, P., Watling, L., Wu, T., and Yasuhara, M.: Biotic and human vulnerability to projected changes in ocean biogeochemistry over the 21st century, PLoS Biol., 11, e1001682, doi:10.1371/journal.pbio.1001682, 2013.

Morato, T., Watson, R., Pitcher, T. J. and Pauly, D.: Fishing down the deep, Fish Fisher., 7, 24-34, 2006.

Morato, T., Kvile, K. Ø., Taranto, G. H., Tempera, F., Narayanaswamy, B. E., Hebbeln, D., Menezes, G. M., Wienberg, C., Santos, R. S., and Pitcher, T. J.: Seamount physiography and biology in the north-east Atlantic and Mediterranean Sea, Biogeosciences, 10, 3039-3054, doi:10.5194/bg-10-3039-2013, 2013.

Morton, B.: Slaughter at sea, Mar. Poll. Bull., 46, 379-380, 2003.

Naether, D. J., Slawtschew, S., Stasik, S., Engel, M., Olzog, M., Wick, L. Y., Timmis, K. N., and Heipieper, H. J.: Adaptation of hydrocarbonoclastic Alcanivorax borkumensis SK2 to alkanes and toxic organic compounds - a physiological and transcriptomic approach, Appl. Environ. Microbiol., 79, 4282-4293, doi:10.1128/AEM.00694-13, 2013.

Narayanaswamy, B. E., Hughes, D. J., Howell, K. L., Davies, J., and Jacobs, C.: First observations of megafaunal communities inhabiting George Bligh Bank, Northeast Atlantic, Deep-Sea Res. Pt. II, 92, 79-86, 2013.

Nauhaus, K., Albrecht, M., Elvert, M., Boetius, A., and Widdel, F.: In vitro cell growth of marine archaeal-bacterial consortia during anaerobic oxidation of methane with sulfate, Environ. Microbiol., 9, 187-196, doi:10.1111/j.1462-2920.2006.01127.x, 2007.

Niemann, H., Losekann, T., de Beer, D., Elvert, M., Nadalig, T., Knittel, K., Amann, R., Sauter, E. J., Schluter, M., Klages, M., Foucher, J. P., and Boetius, A.: Novel microbial communities of the Haakon Mosby mud volcano and their role as a methane sink, Nature, 443, 854-858, 2006

Nihous, G. C.: A preliminary assessment of ocean thermal energy conversion resources, J. Energy Res. Tech., 129, 10-17, 2007.

Norse, E. A., Brooke, S., Cheung, W. W. L., Clark, M. R., Ekeland, I., Froese, R., Gjerde, K. M., Haedrich, R. L., Heppell, S. S., Morato, T., Morgan, L. E., Pauly, D., Sumaila, R., and Watson, R. Sustainability of deep-sea fisheries, Mar. Policy, 36, 307-320, 2012.

Oleson, J. P.: Herodotus, Aristotle, and sounding weights: the deep sea as a frontier in the classical world, J. Roman Archaeol., 13, 293-310, 2000. 
Olu, K., Duperret, A., Sibuet, M., Foucher, J., and Fiala-Mdioni, A.: Structure and distribution of cold seep communities along the Peruvian active margin: relationship to geological and fluid patterns, Mar. Ecol.-Prog. Ser., 132, 109-125, 1996.

O'Neill, R. V.: Is it time to bury the ecosystem concept? (with full military honors, of course!), Ecology, 82, 3275-3284, 2001.

Pailleret, M., Haga, T., Petit, P., Privé-Gill, C., Saedlou, N., Gaill, F., and Zbinden, M.: Sunken wood from the Vanuatu Islands: identification of wood substrates and preliminary description of associated fauna, Mar. Ecol., 28, 233-241, 2007.

Parada, J., Feng, X., Hauerhof, E., Suzuki, R., and Abubakar, U.: The deep sea energy park: harvesting hydrothermal energy for seabed exploration, University of Southampton, Southampton, England, 111 pp., 2012.

Paulmier, A. and Ruiz-Pino, D.: Oxygen minimum zones (OMZs) in the modern ocean, Progr. Oceanogr., 80, 113-128, 2009.

Pham, C. K., Ramirez-Llodra, E., Alt, C. H. S., Amaro, T., Bergmann, M., Canals, M., Company, J. B., Davies, J., Duineveld, G., Galgani, F., Howell, K. L., Huvenne, V. A. I., Isidro, E., Jones, D. O. B., Lastras, G., Morato, T., Gomes-Pereira, J. N., Purser, A., Stewart, H., Tojeira, I., Tubau, X., Van Rooij, D., and Tyler, P. A.: Marine Litter Distribution and Density in European Seas, from the Shelves to Deep Basins, Plos One, 9, e95839, doi:10.1371/journal.pone.0095839, 2014

Pichler, M.: Assesment of hydrogen - rock interactions during geological storage of $\mathrm{CH}_{4}-\mathrm{H}_{2}$ mixtures, MSc thesis at Department Mineral Resources \& Petroleum Engineering Chair of Reservoir Engineering, 97 pp., 2013.

Puig, P., Canals, M., Martín, J., Amblas, D., Lastras, G., Palanques, A., and Calafat, A. M.: Ploughing the deep sea floor, Nature, 489, 286-289, 2012.

Pusceddu, A., Bianchelli, S., Martín, J., Puig, P., Palanques, A., Masqué, P., Danovaro, R.,: 2014. Chronic and intensive bottom trawling impairs deep-sea biodiversity and ecosystem functioning, P. Natl. Acad. Sci., in press, doi:10.1073/pnas.1405454111, 2014.

Ramirez-Llodra, E., Brandt, A., Danovaro, R., De Mol, B., Escobar, E., German, C. R., Levin, L. A., Martinez Arbizu, P., Menot, L., Buhl-Mortensen, P., Narayanaswamy, B. E., Smith, C. R., Tittensor, D. P., Tyler, P. A., Vanreusel, A., and Vecchione, M.: Deep, diverse and definitely different: unique attributes of the world's largest ecosystem, Biogeosciences, 7, 2851-2899, doi:10.5194/bg-7-2851-2010, 2010.

Ramirez-Llodra, E., Tyler, P. A., Baker, M. C., Bergstad, O. A., Clark, M. R., Escobar, E., Levin, L. A., Menot, L., Rowden, A. A., Smith, C. R., and Van Dover, C. L.: Man and the Last Great Wilderness: Human Impact on the Deep Sea, PLoS ONE, 6, e22588, doi:10.1371/journal.pone.0022588, 2011.

Ramirez-Llodra, E., De Mol, B., Company, J. B., Coll, M., and Sardà, F.: Effects of natural and anthropogenic processes in the distribution of marine litter in the deep Mediterranean Sea, Progr. Oceanogr., 118, 273-287, doi:10.1016/j.pocean.2013.07.027, 2013

Reeburgh, W. S.: Oceanic Methane Biogeochemistry, Chem. Rev., 107, 486-513, 2007.

Reinthaler, T., van Aken, H. M., and Herndl, G. J.: Major contribution of autotrophy to microbial carbon cycling in the deep North Atlantic's interior, Deep-Sea Res. Pt. II, 57, 1572-1580, 2010.
Rex, M. A. and Etter, R. J.: Deep-sea biodiversity: pattern and scale, Harvard Univ. Pr., 354 pp. 2010.

Rice, A. L., Thurston, M. H., and New, A. L.: Dense aggregations of a hexactinellid sponge, Pheronema carpenteri, in the Porcupine Seabight (Northeast Atlantic Ocean) and possible causes, Progr. Oceanogr., 24, 179-196, 1990.

Rivers, A. R., Sharma, S., Tringe, S. G., Martin, J., Joye, S. B., and Moran, M. A.: Transcriptional response of bathypelagic marine bacterioplankton to the Deepwater Horizon oil spill, ISME J., 7, 2315-2329, doi:10.1038/ismej.2013.129, 2013.

Roberts, C. M.: Deep impact: the rising toll of fishing in the deep sea, Trends Ecol. Evol., 17, 242-245, 2002.

Roberts, J. M., Wheeler, A. J., and Freiwald, A.: Reefs of the deep: The biology and geology of cold-water coral ecosystems, Science, 312, 543-547, 2006.

Robison, B. H.: Deep pelagic biology, J. Exp. Mar. Biol. Ecol., 300, 253-272, 2004.

Rouse, G. W., Goffredi, S. K., and Vrijenhoek, R. C.: Osedax: Bone-Eating Marine Worms with Dwarf Males, Science, 305, 668-671, 2004.

Rowden, A. A., Clark, M. R., and Wright, I. C.: Physical characterisation and a biologically focused classification of "seamounts" in the New Zealand region, New Zealand J. Mar. Freshw. Res., 39, 1039-1059, 2005.

Ruhl, H. A., Ellena, J. A., and Smith, K. L.: Connections between climate, food limitation, and carbon cycling in abyssal sediment communities, P. Natl. Acad. Sci., 105, 17006-17011, 2008.

Sabine, C. L. and Feely, R. A.: The oceanic sink for carbon dioxide, in: Greenhouse Gas Sinks, edited by: Reay, D., Hewitt, N., Grace, J., and Smith, K., CABI Publishing, Oxfordshire, UK, 31-49, 2007.

Sardá, R., Gil, J., Taboada, S., and Gili, J. M.: Polychaete species captured in sediment traps moored in northwestern Mediterranean submarine canyons, Zool. J. Linn. Soc., 155, 1-21, 2009.

Schmittner, A.: Decline of the marine ecosystem caused by a reduction in the Atlantic overturning circulation, Nature, 434, 628633, doi:10.1038/nature03476, 2005.

Schmitz, S.: "Einfluss von Wasserstoff als Gasbegleitstoff auf Untertagespeicherung", 2011.

Sellanes, J., Pedraza-García, M. J. and Zapata-Hernández, G.: Las áreas de filtración de metano constituyen zonas de agregación del bacalao de profundidad (Dissostichus eleginoides) frente a Chile central?, Lat. Am. J. Aquat. Res., 40, 980-991, 2012.

Serpetti, N., Gontikaki, E., Narayanaswamy, B. E., and Witte, U.: Macrofaunal community inside and outside of the Darwin Mounds Special Area of Conservation, NE Atlantic, Biogeosciences, 10, 3705-3714, doi:10.5194/bg-10-3705-2013, 2013.

Shields, M. A. and Kedra, M.: A deep burrowing sipunculan of ecological and geochemical importance, Deep-Sea Res. Pt. I, 56, 2057-2064, 2009.

Skropeta, D.: Deep-sea natural products, Natural Product Reports 25, 1131, 2008.

Smith, C. R. and Baco, A. R.: Ecology of whale falls at the deep-sea floor, Oceanogr. Mar. Biol., 41, 311-354, 2003.

Smith, C. R., De Leo, F. C., Bernardino, A. F., Sweetman, A. K., and Arbizu, P. M.: Abyssal food limitation, ecosystem structure and climate change, Trends Ecol. Evol., 23, 518-528, 2008.

Smith, C. R., Grange, L. J., Honig, D. L., Naudts, L., Huber, B., Guidi, L., and Domack E.: A large population of king crabs in 
Palmer Deep on the west Antarctic Peninsula shelf and potential invasive impacts, P. R. Soc. B., 279, 1017-1026, 2012.

Smith, D. C., Simon, M., Alldredge, A. L., and Azam, F.: Intense hydrolytic enzyme activity on marine aggregates and implications for rapid particle dissolution, Nature 359, 139-142, 1992.

Sogin, M. L., Morrison, H. G., Huber, J. A., Welch, D. M., Huse, S. M., Neal, P. R., Arrieta, J. M., and Herndl, G. J.: Microbial diversity in the deep sea and the underexplored "rare biosphere," P. Natl. Acad. Sci., 103, 12115-12120, 2006.

Sommer, S., Pfannkuche, O., Linke, P., Luff, R., Greinert, J., Drews, M., Gubsch, S., Pieper, M., Poser, M. and Viergutz, T.: Efficiency of the benthic filter: Biological control of the emission of dissolved methane from sediments containing shallow gas hydrates at Hydrate Ridge, Global Biogeochem. Cy., 20, GB2019, doi:10.1029/2004GB002389, 2006.

Sommer, S., Linke, P., Pfannkuche, O., Niemann, H., and Treude, T.: Benthic respiration in a seep habitat dominated by dense beds of ampharetid polychaetes at the Hikurangi Margin (New Zealand), Mar. Geol., 272, 223-232, 2010.

Strang, C., and Tran, L. U.: National Marine Educations Association, Special Report 3: The Ocean Literacy Campaign, 80 pp., 2010.

Suttle, C. A.: Viruses in the sea, Nature 437, 356-361, 2005.

Swan, B. K.: Martinez-Garcia, M., Preston, C. M., Sczyrba, A., Woyke, T., Lamy, D., Reinthaler, T., Poulton, N. J., Masland, E. D. P., Gomez, M. L., Sieracki, M. E., DeLong, E. F., Herndl, G. J., and Stepanauskas, R.: Potential for chemolithoautotrophy among ubiquitous bacteria lineages in the dark ocean, Science 333, 1296-1300, 2011.

Tavormina, P. L., Ussler, W., and Orphan, V. J.: Planktonic and Sediment-Associated Aerobic Methanotrophs in Two Seep Systems along the North American Margin, Appl. Environ. Microbiol., 74, 3985-3995, 2008.

TEEB: The Economics of Ecosystems and Biodiversity: Ecological and Economic Foundations, in: Earthscan, edited by: Kumar, P., London and Washington. 2010.

Thiel, H.: Anthropogenic impacts on the deep sea, Ecosystems of the World, 427-472, 2003.

Thistle, D., Sedlacek, L., Carman, K. R., Fleeger, J. W., Brewer, P. G., and Barry, J. P.: Simulated sequestration of industrial carbon dioxide at a deep-sea site: Effects on species of harpacticoid copepods, J. Exp. Mar. Biol. Ecol., 330, 151-158, 2006.

Thistle, D., Sedlacek, L., Carman, K. R., Fleeger, J. W., Brewer, P. G., and Barry, J. P.: Exposure to carbon dioxide-rich seawater is stressful for some deep-sea species: an in situ, behavioral study, Mar. Ecol.-Prog. Ser., 340, 9-16, 2007.

Thornburg, C. C., Zabriskie, T. M., and McPhail, K. L.: Deep-Sea Hydrothermal Vents: Potential Hot Spots for Natural Products Discovery?, J. Nat. Prod. 73, 489-499, 2010.

Thurber, A. R., Levin, L. A., Orphan, V. J., and Marlow, J. J.: Archaea in metazoan diets: implications for food webs and biogeochemical cycling, ISME J., 6, 1602-1612, 2012.

Thurber, A. R., Levin, L. A., Rowden, A. A., Sommer, S., Linke, P., and Kröger, K.: Microbes, macrofauna, and methane: A novel seep community fueled by aerobic methanotrophy, Limnol. Oceanogr., 58, 1640-1656, 2013.

Treude, T., Smith, C. R., Wenzhfer, F., Carney, E., Bernardino, A. F., Hannides, A. K., Krger, M., and Boetius, A.: Biogeochem- istry of a deep-sea whale fall: sulfate reduction, sulfide efflux and methanogenesis, Mar. Ecol.-Prog. Ser., 382, 1-21, 2009.

Treude, T., Kiel, S., Linke, P., Peckmann, J., and Goedert, J. L.: Elasmobranch egg capsules associated with modern and ancient cold seeps: A nursery for non-seep marine predators, Mar. Ecol.Prog. Ser., 437, 175-181, 2011.

Turner, R. D.: Wood, mollusks, and deep-sea food chains, B. Am. Malacol. Un., 1976, 13-19, 1977.

UK National Ecosystem Assessment: The UK National Ecosystem Assessment Technical Report, UNEP-WCMC, Cambridge, 2011.

Ulloa, O., Canfield, D. E., DeLong, E. F., Letelier, R. M., and Stewart, F. J.: Microbial oceanography of anoxic oxygen minimum zones, P. Natl. Acad. Sci., 109, 15996-16003, 2012.

Valentine, D. L., Kastner, M., Wardlaw, G. D., Wang, X., Purdy, A., and Bartlett, D. H.: Biogeochemical investigations of marine methane seeps, Hydrate Ridge, Oregon, J. Geophys. Res., 110, G02005, doi:10.1029/2005JG000025, 2005.

Valentine, D. L., Kessler, J. D., Redmond, M. C., Mendes, S. D., Heintz, M. B., Farwell, C., Hu, L., Kinnaman, F. S., Yvon-Lewis, S., Du, M., Chan, E. W., Tigreros, F. G., and Villanueva, C. J.: Propane respiration jump-starts microbial response to a deep oil spill, Science, 330, 208-211, 2010.

Van den Hove, S. and Moreau, V.: Deep-sea Biodiversity and Ecosystems: A Scoping Report on Their Socio-economy, Management and Governanace, UNEP/Earthprint, 2007.

Van Dover, C. L.: The ecology of deep-sea hydrothermal vents, Princeton University Press, Princeton, NJ, 2000.

Van Gaever, S., Moodley, L., Pasotti, F., Houtekamer, M., Middelburg, J. J., Danovaro, R., and Vanreusel, A.: Trophic specialisation of metazoan meiofauna at the Håkon Mosby Mud Volcano: fatty acid biomarker isotope evidence, Mar. Biol., 156, 12891296, 2009.

Vardaro, M. F., Ruhl, H. A., and Smith, K. L.: Climate variation, carbon flux, and bioturbation in the abyssal North Pacific, Limnol. Oceanogr., 54, 2081-2088, 2009.

Vega, L. A.: Ocean Thermal Energy Conversion Primer, Mar. Technol. Soc. J., 36, 25-35, 2002.

Vetter, E. W., Smith, C. R., and De Leo, F. C.: Hawaiian hotspots: enhanced megafaunal abundance and diversity in submarine canyons on the oceanic islands of Hawaii, Mar. Ecol., 31, 183199, 2010.

Vetter, Y., Deming, J., Jumars, P., and Krieger-Brockett, B.: A predictive model of bacterial foraging by means of freely released extracellular enzymes, Microbial Ecol., 36, 75-92, 1998.

Wakeham, S. G., Lewis, C. M., Hopmans, E. C., Schouten, S., and Sinninghe Damsté, J. S.: Archaea mediate anaerobic oxidation of methane in deep euxinic waters of the Black Sea, Geochim. Cosmochim. Ac., 67, 1359-1374, doi:10.1016/S00167037(02)01220-6, 2003.

Wallace, K. J.: Classification of ecosystem services: Problems and solutions, Biol. Conserv., 139, 235-246, 2007.

Wallmann, K. and Bialas, J.: International viewpoint and news, Environ. Earth Sci., 59, 485-487, doi:10.1007/s12665-009-0235-x, 2009.

Wallmann, K., Pinero, E., Burwicz, E., Haeckel, M., Hensen, C., Dale, A. W., and Ruepke, L.; The global inventory of methane hydrate in marine sediments: A theoretical approach, Energies, 5, 2449-2498, 2012. 
Ward, B. B., Devol, A. H., Rich, J. J., Chang, B. X., Bulow, S. E., Naik, H., Pratihary, A., and Jayakumar, A.: Denitrification as the dominant nitrogen loss process in the Arabian Sea, Nature, 461, 78-81, 2009.

Watson, R. A. and Morato, T.: Fishing down the deep: Accounting for within-species changes in depth of fishing, Fish. Res., 140, 63-65, 2013.

Wei, C.-L., Rowe, G. T., Escobar-Briones, E., Boetius, A., Soltwedel, T., Caley, M. J., Soliman, Y., Huettmann, F., Qu, F., Yu, Z., Pitcher, C. R., Haedrich, R. L., Wicksten, M. K., Rex, M. A., Baguley, J. G., Sharma, J., Danovaro, R., MacDonald, I. R., Nunnally, C. C., Deming, J. W., Montagna, P., Lévesque, M., Weslawski, J. M., Wlodarska-Kowalczuk, M., Ingole, B. S., Bett, B. J., Billett, D. S. M., Yool, A., Bluhm, B. A., Iken, K., and Narayanaswamy, B. E.: Global patterns and predictions of seafloor biomass using random forests, PLoS ONE, 5, e15323, doi:10.1371/journal.pone.0015323, 2010.
White, H. K., Hsing, P.-Y., Cho, W., Shank, T. M., Cordes, E. E., Quattrini, A. M., Nelson, R. K., Camilli, R., Demopoulos, A. W., and German, C. R.: Impact of the Deepwater Horizon oil spill on a deep-water coral community in the Gulf of Mexico, P. Natl. Acad. Sci., 109, 20303-20308, 2012.

Whitman, W. B., Coleman, D. C., and Wiebe, W. J.: Prokaryotes: The unseen majority, P. Natl. Acad. Sci., 95, 6578-6583, 1998.

Wolff, T.: Magrofaunal utilization of plant remains in the deep sea, Sarsia, 64, 117-143, 1979.

Wu, G., Lin, A., Gu, Q., Zhu, T., and Li, D.: Four New ChloroEremophilane Sesquiterpenes from an Antarctic Deep-Sea Derived Fungus, Penicillium sp. PR19N-1, Mar. Drugs, 11, 13991408, doi:10.3390/md11041399, 2013.

Wuchter, C., Abbas, B., Coolen, M. J., Herfort, L., van Bleijswijk, J., Timmers, P., Strous, M., Teira, E., Herndl, G. J., and Middelburg, J. J.: Archaeal nitrification in the ocean, P. Natl. Acad. Sci., 103, 12317-12322, 2006.

Yeh, R.-H., Su, T.-Z., and Yang, M.-S.: Maximum output of an OTEC power plant, Ocean Eng., 32, 685-700, 2005. 